\title{
Provenance, tectonics and palaeoclimate of Proterozoic Chandarpur sandstones, Chattisgarh basin: A petrographic view
}

\author{
Basudeb Datta \\ 3, Bidhan Sarani, Kolkata 700 006, West Bengal, India.
}

Sandstones of early Neoproterozoic Chandarpur Group, Chattisgarh Supergroup, central India display progressive change towards greater textural and mineralogical maturity from base to top of the succession. The clay-silt matrix decreases, sorting of sand grains improves, frequency of rounded grains increases, monocrystalline quartz content increases with concomitant decrease in polycrystalline quartz, feldspar and rock fragments. The trend of variations in different mineralogical and textural attributes, however, exhibits inflections at different stratigraphic levels. The sandstones of the basal Lohardih Formation are alluvial fan deposits, characterized by high matrix and feldspar content, iron-oxide impregnated highly angular grains and poor sorting. Petrographic properties collectively indicate that the sandstones were derived from a weathered granitic crust under a humid climatic condition. Abundance of well rounded grains within the alluvial fan and overlying braided fluvial deposit indicates prolonged wind action during episodes of high aridity. The shallow marine deposit overlying the fluvial deposits in the upper part of the Lohardih Formation exhibits bedto-bed variation in the frequency of angular grains, feldspar content and overall maturity suggesting environmentally controlled segregation of sediments. The abrupt appearance of coarse-grained immature sandstones with concomitant reappearance of iron-oxide impregnated/altered feldspar grains in the upper part of the shelf deposits of the Chaporadih Formation point to a phase of tectonic uplift that possibly triggered a regression. Continued regression and peneplanation heralded the deposition of supermature medium-grained purple quartzarenite of the upper shoreface Kansapathar Formation in the uppermost part of the Chandarpur succession under a hot desertic climatic condition. The provenance analysis revealed that the Chandarpur clastics were derived from granites and granite-gneisses of a continental block tectonic provenance. Petrographic studies further indicate that high grade metamorphic rocks did not make any perceptible contribution to the Chandarpur system. The Eastern Ghats Granulite Belt apparently did not emerge till the early Neoproterozoic.

\section{Introduction}

The Chattisgarh is a major Proterozoic (Purana) basin (Holland 1906) in the central part of the Indian craton and comprises a thick succession of sandstone, shale and limestone, known as the Chattisgarh Supergroup (Naqvi and Rogers 1987; Murti 1987, 1996; Das et al 1992; Datta 1998; Das et al 2001). The lower part of the succession is dominated by sandstone (Chandarpur Group) whereas limestone and shale dominate the upper part (Raipur Group). K-Ar dating of authigenic glauconite from the lower part of the Chattisgarh succession yields an age of 700-750 Ma (Kreuzer et al 1977). The succession has so far been studied mainly from the point of view of lithostratigraphy, lithofacies and palaeogeography (Murti 1987, 1996; Das et al 1992; Moitra 1995; Datta 1998; Gupta

Keywords. Sandstones; Chandarpur Group; Chattisgarh; provenance; tectonics; palaeoclimate. 


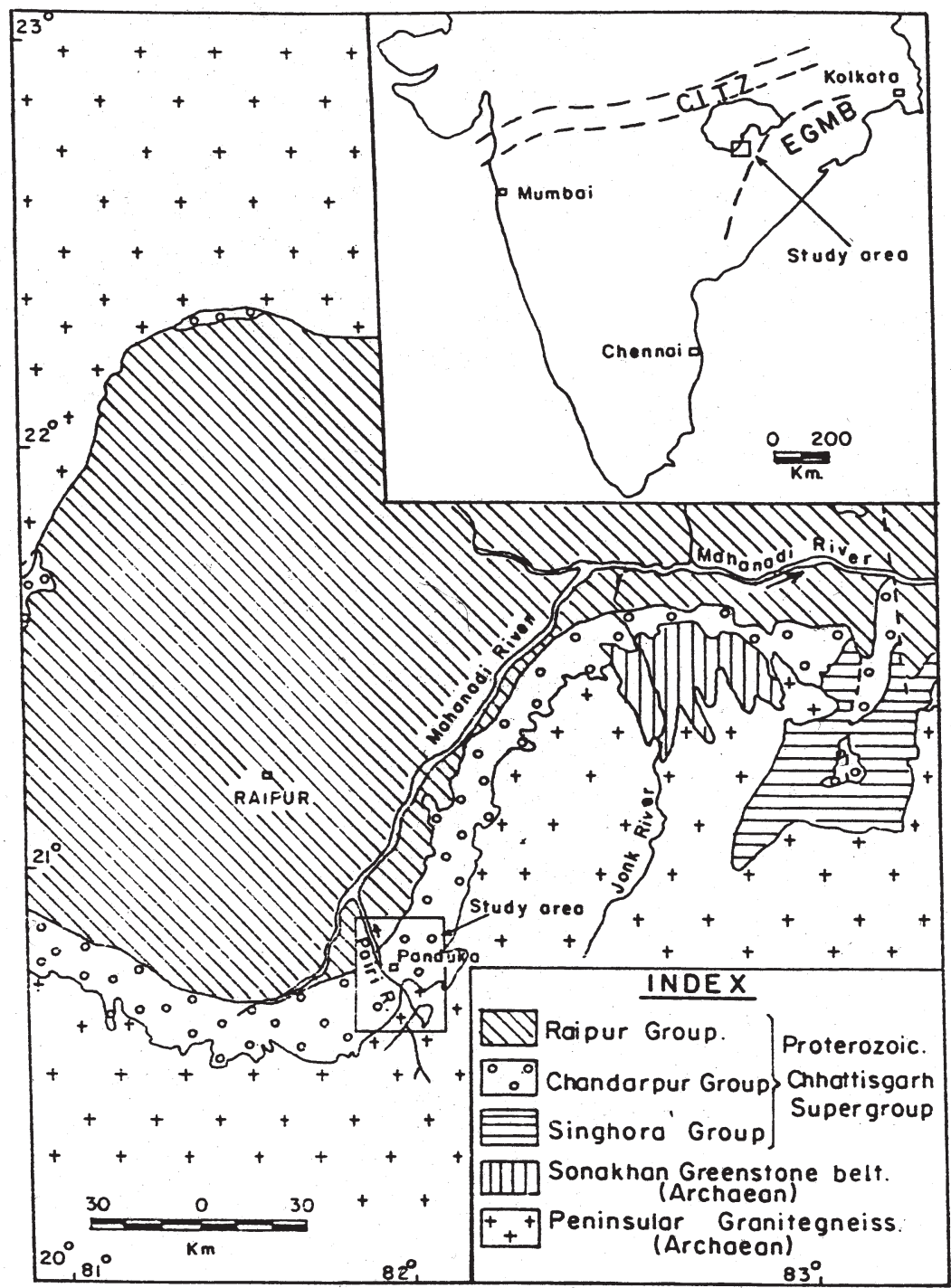

Figure 1. Generalised geological map of the Proterozoic Chattisgarh Supergroup; box marks the study area. (CITZ: Central Indian Tectonic Zone; EGMB: Eastern Ghats Mobile Belt.)

1998; Datta et al 1999; Patranabis Deb and Chaudhuri 2002). However, there is no report of detailed petrographic work from the Chattisgarh succession, though petrographic work is an integral part of any comprehensive sedimentological study and is of paramount importance for studying provenance, palaeoclimate and tectonics.

The present study is focussed on the petrography of the Chandarpur Group around Panduka village $\left(20^{\circ} 48^{\prime} \mathrm{N}, 81^{\circ} 56^{\prime} \mathrm{E}\right)$, Chattisgarh, along the southern margin of the Chattisgarh outcrop (figure 1). The sandstones and sandy matrix of conglomerates show wide variation in compositional and textural parameters. The wide range of petrographic variations provides excellent opportunities for tracing petrographic changes in relation to changing environmental dynamics. Besides the analysis of time- or environment-related changes, a major emphasis of the present study is directed towards provenance studies, recognition of palaeoclimate and the tectonic regime.

\section{Geologic setting and depositional environment of the Chandarpur Group}

The Chandarpur Group comprises unmetamorphosed and gently dipping subhorizontal beds of sandstones with conglomerate and shale as subordinate constituents. The succession unconformably overlies gneisses, granitoids and the Sonakhan greenstone belt of the Archaean basement complex (figure 1). The succession is bounded by the Central Indian Tectonic Zone (CITZ) in the north (figure 1). In the east, granitoids, granulites and associated high grade rocks of the Eastern Ghats Granulite Belt fringe the basin, whereas, it is delineated in the west by the Kotri volcanics and the 
Table 1. Stratigraphic succession of the Chandarpur Group around Panduka, southern part of Chattisgarh.

\begin{tabular}{|c|c|c|c|}
\hline Formation & Unit/facies association/assemblage & Palaeocurrent & $\begin{array}{l}\text { Depositional } \\
\text { environment }\end{array}$ \\
\hline \multicolumn{4}{|c|}{$\begin{array}{l}\text { Chattisgarh Supergroup } \\
\text { Raipur Group }\end{array}$} \\
\hline \multicolumn{4}{|l|}{ Chandarpur Group } \\
\hline $\begin{array}{l}\text { Kansapathar } \\
\text { Formation } \\
(20-40 \mathrm{~m})\end{array}$ & $\begin{array}{l}\text { Unit-4: } \\
\text { Swaley and large trough cross-stratified } \\
\text { medium-grained purple quartzarenite. }\end{array}$ & $\begin{array}{l}\text { NNW-SSE or } \\
\mathrm{N}-\mathrm{S} \text { (orientation } \\
\text { of swales) }\end{array}$ & Upper shoreface \\
\hline $\begin{array}{l}\text { Chaporadih } \\
\text { Formation } \\
(2-10 \mathrm{~m})\end{array}$ & $\begin{array}{l}\text { Unit-3: } \\
\text { Plane laminated mudstone, fine sandstones } \\
\text { with HCS, and megarippled coarse subarkose. }\end{array}$ & $\begin{array}{l}\text { NNE-SSW } \\
\text { (orientation of } \\
\text { megaripples) }\end{array}$ & $\begin{array}{l}\text { Inner to outer } \\
\text { shelf }\end{array}$ \\
\hline \multirow[t]{4}{*}{$\begin{array}{l}\text { Lohardih } \\
\text { Formation }\end{array}$} & $\begin{array}{l}\text { Unit-2: }(60-90 \mathrm{~m}) \\
\text { Unit-2B: Lenticular, cross-stratified and } \\
\text { bidirectional large planar cross-stratified } \\
\text { coarse subarkose, mega-rippled medium } \\
\text { subarkose, ripple to wavy laminated } \\
\text { medium to fine subarkose to quartzarenite } \\
\text { and subordinate mudstone. }\end{array}$ & $\begin{array}{l}\text { NNE-SSW } \\
\text { (orientation of } \\
\text { mega-ripples) }\end{array}$ & $\begin{array}{l}\text { Wave-tide } \\
\text { dominated } \\
\text { shallow subtidal } \\
\text { (shoreface) to } \\
\text { intertidal }\end{array}$ \\
\hline & $\begin{array}{l}\text { Unit-2A: Small trough and large planar sim- } \\
\text { ple to compound cross-stratified lenticular } \\
\text { to sheets of white feldspar bearing coarse- } \\
\text { grained subarkose. }\end{array}$ & $\begin{array}{l}\text { Strongly } \\
\text { unidirectional } \\
\text { southeasterly } \\
\text { palaeoflow }\end{array}$ & Braided fluvial \\
\hline & $\begin{array}{l}\text { Unit-1: }(0-30 \mathrm{~m}) \\
\text { Facies assemblage-1a: Massive, crude } \\
\text { plane-stratified to trough cross-stratified } \\
\text { conglomerate, pebbly sandstone and pink } \\
\text { feldspar bearing coarse-grained cross- } \\
\text { stratified arkose. } \\
\text { Facies assemblage-1b: Coarse-grained } \\
\text { plane-stratified arkose, pebble sheets and } \\
\text { mudstone. }\end{array}$ & $\begin{array}{l}\text { Unidirectional } \\
\text { southeasterly } \\
\text { palaeoflow }\end{array}$ & Alluvial fan \\
\hline & Granitic and granite-gneissic Archaea & ment rocks & \\
\hline
\end{tabular}

Chilpi Group of rocks along a N-S trending fault (Das et al 1992). Porphyritic granite with pink feldspar is the most common crystalline basement rock.

The Chandarpur succession has been classified into four mappable units on the basis of composition, texture and colour. The four units are conglomerate and pink feldspar-bearing arkose (unit-1), white feldspar-bearing subarkose (unit-2), mudstone dominated unit with intercalated sandstones (unit-3), and purple quartzarenite (unit-4) in ascending order. The unit-2 is further subdivided into two parts, unit-2A and $2 \mathrm{~B}$, on the basis of inferred depositional environments. The units have been grouped into three formations namely, Lohardih, Chaporadih and Kansapathar Formations (Datta 1998). The lithostratigraphic succession, dominant facies and depositional environments of the formations/units of the Chandarpur group are summarised in table 1 .

The rocks of the Chandarpur group were deposited primarily in alluvial fan, braided fluvial, wave-tide dominated shallow subtidal (shoreface) to intertidal, and shelf environments (Datta 1998). The environments of deposition for different units were determined by detailed analysis of lithofacies and facies association, sand body geometry and palaeocurrents (see table 1). The succession from the base of the Lohardih Formation to the lower part of the Chaporadih Formation represents a fining-up transgressive cycle which was followed up by a regressive cycle represented by the upper part of the Chaporadih Formation and the Kansapathar Formation. The fan and fluvial depositional 
Table 2. Generalized modal compositions of sandstones of the Chandarpur Group.

\begin{tabular}{|c|c|c|c|c|c|c|c|c|c|c|}
\hline Formations & Units & Samples & Quartz & Feldspar & $\begin{array}{l}\text { Rock Fr } \\
\text { Granite }\end{array}$ & $\begin{array}{l}\text { sment } \\
\text { Sed. }\end{array}$ & Others & Cement & Matrix & $\begin{array}{c}\text { Total grains } \\
\text { counted }\end{array}$ \\
\hline Kansapathar & Unit-4 & $260 \mathrm{~B}$ & 73.6 & & & 1.6 & 4.6 & 20.1 & 0.1 & 700 \\
\hline \multirow[t]{4}{*}{ Formation } & & 209B & 73.4 & & & & 1.3 & 23.4 & 1.9 & 800 \\
\hline & & $262 \mathrm{~B}$ & 65.7 & 0.5 & & 0.3 & 13.5 & 20.0 & & 600 \\
\hline & & $208 B$ & 74.5 & 0.7 & & & 2.6 & 22.2 & & 600 \\
\hline & & $229 \mathrm{~B}$ & 65.4 & 1.4 & & 0.4 & 5.4 & 27.4 & & 1000 \\
\hline Chaporadih & Unit-3 & 202iAm & 69.0 & 6.6 & 0.3 & & & 24.1 & & 700 \\
\hline \multirow[t]{7}{*}{ Formation } & & 207Am & 77.6 & 8.1 & 1.9 & 4.4 & 2.4 & 5.0 & 0.6 & 800 \\
\hline & & 218Am & 81.6 & 10.2 & 2.8 & & 1.5 & 3.2 & 0.7 & 600 \\
\hline & & $256 \mathrm{C}$ & 44.2 & 6.2 & & 3.4 & 8.8 & 13.6 & 23.8 & 500 \\
\hline & & $210(\mathrm{bl}) \mathrm{C}$ & 46.8 & 8.3 & & 35.1 & 1.9 & 5.3 & 2.6 & 700 \\
\hline & & $210(\mathrm{gl}) \mathrm{C}$ & 60.4 & 16.4 & & 2.0 & 12.0 & 5.2 & 4.0 & 500 \\
\hline & & $257 \mathrm{C}$ & 52.6 & 17.9 & & & 6.0 & 4.8 & 18.7 & 700 \\
\hline & & $202 \mathrm{~A} 2$ & 61.2 & 19.2 & & 2.5 & 5.0 & 2.8 & 9.3 & 600 \\
\hline Lohardih & Unit-2B & $232 / 1 \mathrm{~T}$ & 83.0 & 4.0 & & & 0.5 & 5.2 & 7.3 & 600 \\
\hline \multirow{16}{*}{ Formation } & & $244 \mathrm{~T}$ & 65.5 & 7.3 & & & 4.5 & 22.7 & & 600 \\
\hline & & $253 / 2 \mathrm{~T}$ & 80.2 & 7.4 & & & 0.8 & 9.0 & 2.6 & 500 \\
\hline & & $213 / 1 \mathrm{~T}$ & 70.0 & 12.4 & 0.4 & 0.6 & 1.0 & 10.4 & 5.2 & 500 \\
\hline & & $211 \mathrm{~T}$ & 74.3 & 19.0 & & 4.1 & 0.9 & 1.1 & 0.6 & 800 \\
\hline & & $212 \mathrm{~A}$ & 72.6 & 13.6 & 0.5 & & 2.5 & 0.8 & 10.0 & 800 \\
\hline & & $250 \mathrm{~A}$ & 72.3 & 13.7 & 5.3 & & 3.3 & 4.7 & 0.7 & 600 \\
\hline & & $300 \mathrm{~A}$ & 66.4 & 19.8 & 0.5 & 2.1 & 0.2 & 7.4 & 3.6 & 800 \\
\hline & Unit-2A & $254 \mathrm{ThDE}$ & 58.7 & 16.8 & & & 3.3 & 14.6 & 6.6 & 700 \\
\hline & & $227 \mathrm{E}$ & 72.9 & 16.4 & 2.7 & & 1.4 & 4.6 & 2.0 & 900 \\
\hline & & $213 / 6 \mathrm{E}$ & 69.4 & 19.8 & & & 2.2 & 7.5 & 1.1 & 800 \\
\hline & & $213 / 4 \mathrm{DE}$ & 65.5 & 20.2 & 0.2 & & 2.3 & 11.6 & 0.2 & 600 \\
\hline & Unit-1 & $215 / 2 \mathrm{D}$ & 61.2 & 20.8 & & & 0.8 & 15.7 & 1.5 & 800 \\
\hline & & $253 \mathrm{D}$ & 55.1 & 21.3 & 1.1 & & 0.8 & 15.3 & 6.4 & 900 \\
\hline & & 319D & 43.4 & 24.2 & 0.4 & 0.6 & 6.9 & 18.1 & 6.4 & 800 \\
\hline & & $245 /$ IID & 48.2 & 24.3 & 5.7 & & 8.0 & 12.0 & 1.8 & 600 \\
\hline & & $241^{\prime} \mathrm{D}$ & 49.6 & 28.0 & 6.0 & & 2.0 & 12.3 & 2.1 & 700 \\
\hline
\end{tabular}

systems of the Lohardih Formation (unit-1 and unit-2A) show a strong unidirectional southeasterly palaeocurrent. Symmetrical megaripples in the overlying shallow subtidal to intertidal deposits (unit-2B) of the Lohardih Formation and the coarse-grained megaripples within the mudstone dominated shelf deposits of the Chaporadih Formation (unit-3) exhibit NNE-SSW trend of their crest lines indicating a shoreline grossly along that trend. Highly consistent orientation of elliptical swales (Datta et al 1999) in the upper shoreface deposits of the Kansapathar Formation indicates that the shoreline might have been changed from NNE-SSW to NNW-SSE or N-S during the later part of Chandarpur sedimentation.

\section{Methodology}

Mineralogical composition of the sandstone was determined by modal analysis with about 5001000 points counted for each thin section (table 2). Grain size was analysed by measuring apparent long axes of 200-300 grains per thin section (table 4). The statistical parameters were obtained following the method of Folk and Ward (1957). The grain roundness was measured by visual comparison of all the grains used in size measurement with the standard chart of Powers (1953).

The sandstone classification proposed by Folk (1980) has been followed in the present study. The modal analysis data were recalculated on a matrix-free basis and was plotted in the QFL diagram (figure 2 and table 3 ). Polycrystalline quartz, though not as durable as monocrystalline quartz, was placed at Q-pole to obviate the problems of distinction between plutonic polycrystalline quartz and metaquartzite fragments. In the triangular diagram constructed for delineating the tectonic setting of the provenance, polycrystalline quartz was placed at the RF pole (in the $\mathrm{L}_{\mathrm{t}}$ pole of $\mathrm{Q}_{\mathrm{m}} \mathrm{FL}_{\mathrm{t}}$ plot of Dickinson and Suczek 1979). Chert was placed at the rock fragment pole as its origin can be unequivocally traced to a sedimentary source, though it was plotted at the Q-pole by several earlier workers (Blatt 1967; Pettijohn et al 1987). Klein (1963) argued that chert is less stable than quartz during transport and placed the chert fragment at the 


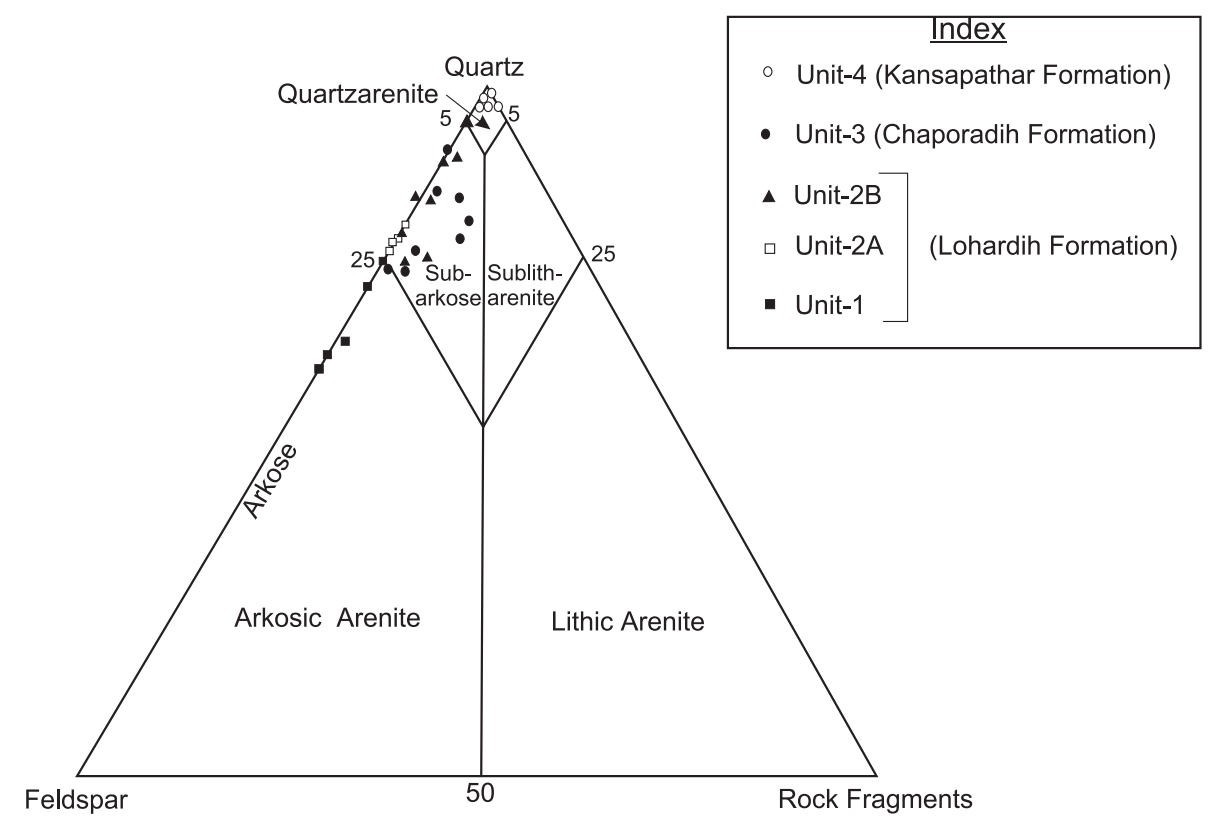

Figure 2. QFL - triangular plot for classification of different sandstone samples from the Chandarpur Group.

RF-pole (also see Folk 1980). The F-pole comprises all types of feldspar grains, and granite and gneissic rock fragments.

The stratigraphic changes in compositional and textural attributes of the sandstones in relation to depositional environments has been analysed by plotting the data along a composite vertical profile covering the complete succession (figures 3 and 4).

For recognition of source rock lithology and tectonic setting of the provenance, the modal analysed data were plotted in the diamond diagram of Basu et al (1975) (figure 5) and Tortosa et al (1991) (figure 6), as well as $\mathrm{Q}_{\mathrm{t}} \mathrm{FL}$ and $\mathrm{Q}_{\mathrm{m}} \mathrm{FL}_{\mathrm{t}}$ triangular diagrams of Dickinson and Suczek (1979) (figures 7 and 8). In $\mathrm{Q}_{\mathrm{t}} \mathrm{FL}$ diagram, all quartzose grains were plotted together; the emphasis was on grain stability and consequently on weathering and relief in the provenance, transport mechanism, as well as composition of the source rock. In $\mathrm{Q}_{\mathrm{m}} \mathrm{FL}_{\mathrm{t}}$ diagram all lithic fragments were plotted together and emphasis was shifted towards the grain size of the source rocks, because finer-grained rocks yield more lithic fragments in the sand-size range. The $Q_{p} L_{v} L_{s}$ and $\mathrm{Q}_{\mathrm{m}} \mathrm{PK}$ diagrams have not been used because $\mathrm{L}_{\mathrm{v}}$, $\mathrm{L}_{\mathrm{s}}$ and $\mathrm{P}$ occur in very minor quantity.

\section{Petrographic description of different units}

\subsection{Lohardih Formation: Conglomerate and pink feldspar-bearing arkose (unit-1)}

Conglomerate and pink arkose dominate the alluvial fan deposits of unit-1. Conglomerates are both clast and matrix (sand) supported; the clasts are angular to subrounded and comprise mostly vein quartz, pink feldspar with a few granite and chert fragments. They range from $86-11 \mathrm{~mm}$ in diameter. The arkose abounds in pink potash feldspar that imparts a pink colour to the rock. The arkose is medium to coarse-grained (grain size of conglomerates and granule-rich sandstones was not measured), and is generally poorly sorted (table 4 and figure 9). The grains are mostly angular, and frequency of well rounded grains increases up the succession (table 4 and figure 10). In general, coarser grains tend to be more rounded, though in a few samples well rounded grains occur in almost all size grades, and in a few others, coarse angular grains coexist with finer rounded grains (figure 9).

Quartz constitutes about $43-61 \%$ of the arkoses where monocrystalline undulatory quartz is most common; polycrystalline and nonundulatory monocrystalline quartz occur in subordinate proportion (tables 2 and 3). In a majority of polycrystalline grains, subgrains with both straight and sutured contacts are common; stretched metamorphic quartz grains (Folk 1980) are rare. Feldspar constitutes about $21-28 \%$ of the rocks. Orthoclase is the most common type; microcline and perthite occur in subordinate amount. Plagioclase feldspar is conspicuously absent. In the lower part of the unit, most of the feldspar grains are altered in varying degrees (figures 9 and 10). Fresh, well rounded feldspar grains are common in the upper part of the unit, where they may locally coexist with altered ones in the same thin section. Clay minerals have developed extensively along cleavages, fractures and twin surfaces of altered feldspar grains. 
Table 3. Quartz (Q), feldspar (F) and lithic fragment (L) proportions in sandstones of the Chandarpur Group used in the QFL plot for sandstone classification.

\begin{tabular}{|c|c|c|c|c|c|c|c|c|}
\hline & & & & Modal abu & lance & & & \\
\hline & & & & $\mathrm{F}$ & $\mathrm{L}$ & Afte & lculat & 100 \\
\hline Formations & Units & Samples & $\left(Q_{m}+Q_{p}\right)$ & $\left(\mathrm{F}+\mathrm{RF}_{\mathrm{Gr}}\right)$ & $\left(\mathrm{RF}_{\mathrm{Sed}}+\right.$ Chert $)$ & $\mathrm{Q}$ & $\mathrm{F}$ & $\mathrm{L}$ \\
\hline Kansapathar & Unit-4 & $260 \mathrm{~B}$ & 73.6 & & 1.9 & 97.5 & & 2.5 \\
\hline Formation & & 209B & 73.4 & & 0.6 & 99.1 & & 0.9 \\
\hline & & $262 \mathrm{~B}$ & 65.7 & 0.5 & 1.0 & 97.8 & 0.7 & 1.5 \\
\hline & & 208B & 74.5 & 0.7 & 0.2 & 98.9 & 0.9 & 0.2 \\
\hline & & $229 \mathrm{~B}$ & 65.4 & 1.4 & 0.4 & 97.3 & 2.1 & 0.6 \\
\hline Chaporadih & Unit-3 & 202iAm & 69.0 & 6.9 & & 91.0 & 9.0 & \\
\hline Formation & & 207Am & 77.6 & 10.0 & 4.8 & 83.9 & 10.8 & 5.3 \\
\hline & & 218Am & 81.6 & 13.0 & 1.3 & 85.1 & 13.5 & 1.4 \\
\hline & & $256 \mathrm{C}$ & 44.2 & 6.2 & 4.2 & 80.9 & 11.4 & 7.7 \\
\hline & & $210(\mathrm{bl}) \mathrm{C}$ & 46.8 & 8.3 & 4.9 & 78.1 & 13.8 & 8.1 \\
\hline & & $210(\mathrm{gl}) \mathrm{C}$ & 60.4 & 16.4 & 2.6 & 76.1 & 20.6 & 3.3 \\
\hline & & $257 \mathrm{C}$ & 52.6 & 17.9 & 0.6 & 74.0 & 25.2 & 0.8 \\
\hline & & $202 \mathrm{~A} 2$ & 61.2 & 19.2 & 3.0 & 73.4 & 23.0 & 3.6 \\
\hline Lohardih & Unit-2B & $232 / 1 \mathrm{~T}$ & 83.0 & 4.0 & & 95.4 & 4.6 & \\
\hline Formation & & $244 \mathrm{~T}$ & 65.5 & 7.3 & & 89.9 & 10.1 & \\
\hline & & $253 / 2 \mathrm{~T}$ & 80.2 & 7.4 & 0.6 & 90.9 & 8.4 & 0.7 \\
\hline & & $213 / 1 \mathrm{~T}$ & 70.0 & 12.8 & 0.8 & 83.7 & 15.3 & 1.0 \\
\hline & & $211 \mathrm{~T}$ & 74.3 & 19.0 & 4.7 & 75.8 & 19.4 & 4.8 \\
\hline & & $212 \mathrm{~A}$ & 72.6 & 14.1 & & 83.7 & 16.3 & \\
\hline & & $250 \mathrm{~A}$ & 72.3 & 19.0 & & 79.2 & 20.8 & \\
\hline & & $300 \mathrm{~A}$ & 66.4 & 20.3 & 2.1 & 74.8 & 22.8 & 2.4 \\
\hline & Unit-2A & $254 \mathrm{ThDE}$ & 58.7 & 16.8 & & 77.7 & 22.3 & \\
\hline & & $227 \mathrm{E}$ & 72.9 & 19.1 & & 79.2 & 20.8 & \\
\hline & & $213 / 6 \mathrm{E}$ & 69.4 & 19.8 & & 77.8 & 22.2 & \\
\hline & & $213 / 4 \mathrm{DE}$ & 65.5 & 20.4 & & 76.3 & 23.7 & \\
\hline & Unit-1 & $215 / 2 \mathrm{D}$ & 61.2 & 20.8 & & 74.7 & 25.3 & \\
\hline & & $253 \mathrm{D}$ & 55.1 & 22.4 & & 71.1 & 28.9 & \\
\hline & & 319D & 43.4 & 24.6 & 0.6 & 63.2 & 35.9 & 0.9 \\
\hline & & $245 / \mathrm{IID}$ & 48.2 & 30.0 & & 61.6 & 38.4 & \\
\hline & & $241^{\prime} \mathrm{D}$ & 49.6 & 34.0 & & 59.3 & 40.7 & \\
\hline
\end{tabular}

Many of the feldspar grains are strongly stained and impregnated with iron-oxide (figures 9 and 10). Granite fragments are the most common rock fragments, and may range up to $6 \%$ in the basal part of the unit (table 2). Mica may range up to $7 \%$ in the beds capping the basement. Large mica flakes, mostly bleached biotites, are commonly deformed and appear as micaceous hash. Heavy minerals are rare, and are dominated by zircon and sphene. The matrix content decreases upwards and eventually almost disappears in the upper part of the unit. Iron-oxide is the dominant cement and occurs as isolated patches within the matrix and interstitial spaces, as grain coating or along cleavages and fractures of detrital grains (figures 9 and 10). In the lower part of the unit, both framework grains and matrix are heavily iron-stained, whereas in the upper part, only the grains are coated with ironoxide. Quartz cement ( $>1-13 \%)$ occurs primarily as overgrowth around detrital quartz grains, in optical continuity with the cores. The overgrown rims are free of iron-oxide stains, but are separated from the core by a sheath of iron-oxide (figure 10). Authigenic feldspar, developed as optically continuous overgrown rim around detrital feldspar grains, occurs in minor quantity.

\subsubsection{Interpretation}

The high incidence of potash feldspar and granite fragments suggests that the detritus were derived from a granitic source (Blatt 1967; Basu 1976). Poor sorting, high amount of mica and primary matrix, high frequency of large angular clasts and very angular grains at the basal part of the unit collectively point to a near source derivation of detritus, rapid deposition and insignificant reworking (Basu 1976; Nemec and Steel 1984; Blair and McPherson 1994a and b). The abundance of sharp reentrants, edges and tongues/apophyses in many framework grains immediately overlying the basement also suggest an almost in situ derivation of the sediments from the weathered granitic basement (Crook 1968). The decreasing abundance of 
Table 4. Grain roundness, mean size $\left(M_{\mathrm{Z}}\right)$, and standard deviation $\left(\sigma_{\mathrm{I}}\right)$ of sandstones of the Chandarpur Group.

\begin{tabular}{|c|c|c|c|c|c|c|}
\hline \multirow[b]{2}{*}{ Units } & \multirow{2}{*}{$\begin{array}{c}\text { Sample } \\
\text { no. }\end{array}$} & \multicolumn{2}{|c|}{ Roundness } & \multirow{2}{*}{$\begin{array}{l}\text { Mean } \\
\left(\mathrm{M}_{\mathrm{Z}}\right) \phi\end{array}$} & \multirow{2}{*}{$\begin{array}{c}\text { Standard } \\
\text { deviation }\left(\sigma_{\mathrm{I}}\right)\end{array}$} & \multirow{2}{*}{$\begin{array}{c}\text { Total grains } \\
\text { measured }\end{array}$} \\
\hline & & Angular (\%) & Rounded (\%) & & & \\
\hline Kansapathar & FL-9B & 1.50 & 98.50 & 1.27 & 0.52 & 200 \\
\hline \multirow{4}{*}{$\begin{array}{l}\text { Formation } \\
\text { (unit-4) }\end{array}$} & $376 \mathrm{~B}$ & 7.50 & 92.50 & 1.35 & 0.46 & 200 \\
\hline & $363 \mathrm{aB}$ & 8.00 & 92.00 & 1.17 & 0.48 & 200 \\
\hline & $229 \mathrm{~B}$ & 12.34 & 87.66 & 1.15 & 0.80 & 300 \\
\hline & 209B & 15.00 & 85.00 & 1.02 & 0.54 & 240 \\
\hline Chaporadih & 202iAm & 16.50 & 83.50 & 0.47 & 1.08 & 230 \\
\hline \multirow{6}{*}{$\begin{array}{l}\text { Formation } \\
\text { (unit-3) }\end{array}$} & FL-8Am & 31.50 & 68.50 & 0.70 & 1.18 & 200 \\
\hline & $239 / 1 \mathrm{Am}$ & 42.00 & 58.00 & -0.32 & 0.67 & 100 \\
\hline & FL-5T/C & 42.00 & 58.00 & 1.76 & 0.60 & 100 \\
\hline & $376 \mathrm{iiT} / \mathrm{C}$ & 46.00 & 54.00 & 1.77 & 0.80 & 100 \\
\hline & $210 \mathrm{C}$ & 61.00 & 39.00 & 1.32 & 0.68 & 200 \\
\hline & $258 \mathrm{C}$ & 75.60 & 24.40 & 3.10 & 0.65 & 250 \\
\hline Lohardih & $244 \mathrm{~T}$ & 11.60 & 88.40 & 1.21 & 0.66 & 250 \\
\hline \multirow{9}{*}{$\begin{array}{l}\text { Formation } \\
\text { (unit-2B) }\end{array}$} & PH-7T & 17.00 & 83.00 & 1.63 & 0.65 & 100 \\
\hline & FL-8B/T & 24.00 & 76.00 & 1.67 & 0.67 & 100 \\
\hline & RH-8T & 27.00 & 73.00 & 1.29 & 0.59 & 100 \\
\hline & $213 / 1 \mathrm{~T}$ & 55.65 & 44.35 & 1.42 & 0.59 & 230 \\
\hline & RH-7A & 12.00 & 88.00 & 0.11 & 0.83 & 200 \\
\hline & RH-4A & 17.50 & 82.50 & 1.23 & 1.47 & 200 \\
\hline & RH-1A & 26.00 & 74.00 & 1.15 & 1.15 & 200 \\
\hline & $376 \mathrm{~A}$ & 27.00 & 73.00 & 0.73 & 1.24 & 100 \\
\hline & $250 \mathrm{~A}$ & 72.00 & 28.00 & 1.55 & 1.14 & 300 \\
\hline Lohardih & PH-4DE & 11.50 & 88.50 & 0.91 & 1.05 & 200 \\
\hline Formation & $254 \mathrm{ThDE}$ & 44.40 & 55.60 & 0.98 & 0.86 & 250 \\
\hline \multirow[t]{2}{*}{ (unit-2A) } & FL-3E & 50.00 & 50.00 & 0.97 & 0.84 & 200 \\
\hline & $213 / 6 \mathrm{E}$ & 73.20 & 26.80 & 0.98 & 1.23 & 250 \\
\hline Lohardih & $230 \mathrm{D}$ & 42.50 & 57.50 & 1.08 & 0.63 & 200 \\
\hline Formation & FL-1D & 43.00 & 57.00 & 0.50 & 1.33 & 200 \\
\hline \multirow[t]{4}{*}{ (unit-1) } & PH-2D & 43.00 & 57.00 & 0.75 & 1.18 & 200 \\
\hline & $253 \mathrm{D}$ & 68.50 & 31.50 & 0.98 & 0.85 & 200 \\
\hline & $254 / 2 \mathrm{D}$ & 76.50 & 23.50 & 0.33 & 1.20 & 200 \\
\hline & $245 /$ IID & 80.00 & 20.00 & 1.07 & 1.33 & 300 \\
\hline
\end{tabular}

iron-oxide up the succession indicates that ironoxide formed primarily in the weathered profile. The coexistence of differentially altered grains of feldspar also points to alteration of feldspar primarily in the weathered profile in the provenance. The ferruginous weathered crust, or extensive alteration of feldspar may indicate wet tropical or subtropical climatic regime (Basu 1976). Nevertheless, highly rounded grains of fresh feldspar are a strong indicator of intense eolian activity (Kuenen 1959, 1960; Chaudhuri 1977) and a possible climatic shift towards aridity during sedimentation of the upper part of this unit.

The bimodality of grain roundness with coexistence of well rounded and angular grains implies that rounding of the grains was not accomplished in the final depositional site (Folk 1960), and may be attributed to mixing of grains transported in aqueous and eolian medium (Chaudhuri 1977). Fluvial transport does not significantly abrade or round sand particles (Folk 1960; Blatt 1967;
Basu 1976; Breyer and Bart 1978; Suttner et al 1981; Franzinelli and Potter 1983; Suttner and Dutta 1986). Intense and prolonged wind reworking and abrasion on alluvial fan surfaces, braid plains and sandflats or in the catchment area generated large amount of highly rounded grains that were admixed with water-borne detritus to produce the roundness bimodality.

\subsection{Lohardih Formation: White feldspar- bearing subarkose (unit-2)}

This unit is subarkosic in composition (tables 2 and 3 ; figure 2) where the feldspar grains, both orthoclase and microcline, are white. The lower part of unit-2 represents braided fluvial deposits (unit2A), whereas the upper part comprises deposits of wave and tide dominated shallow subtidal to tidal flat environments (unit-2B). The petrographic characters of sandstones however, do not exhibit any marked difference. 

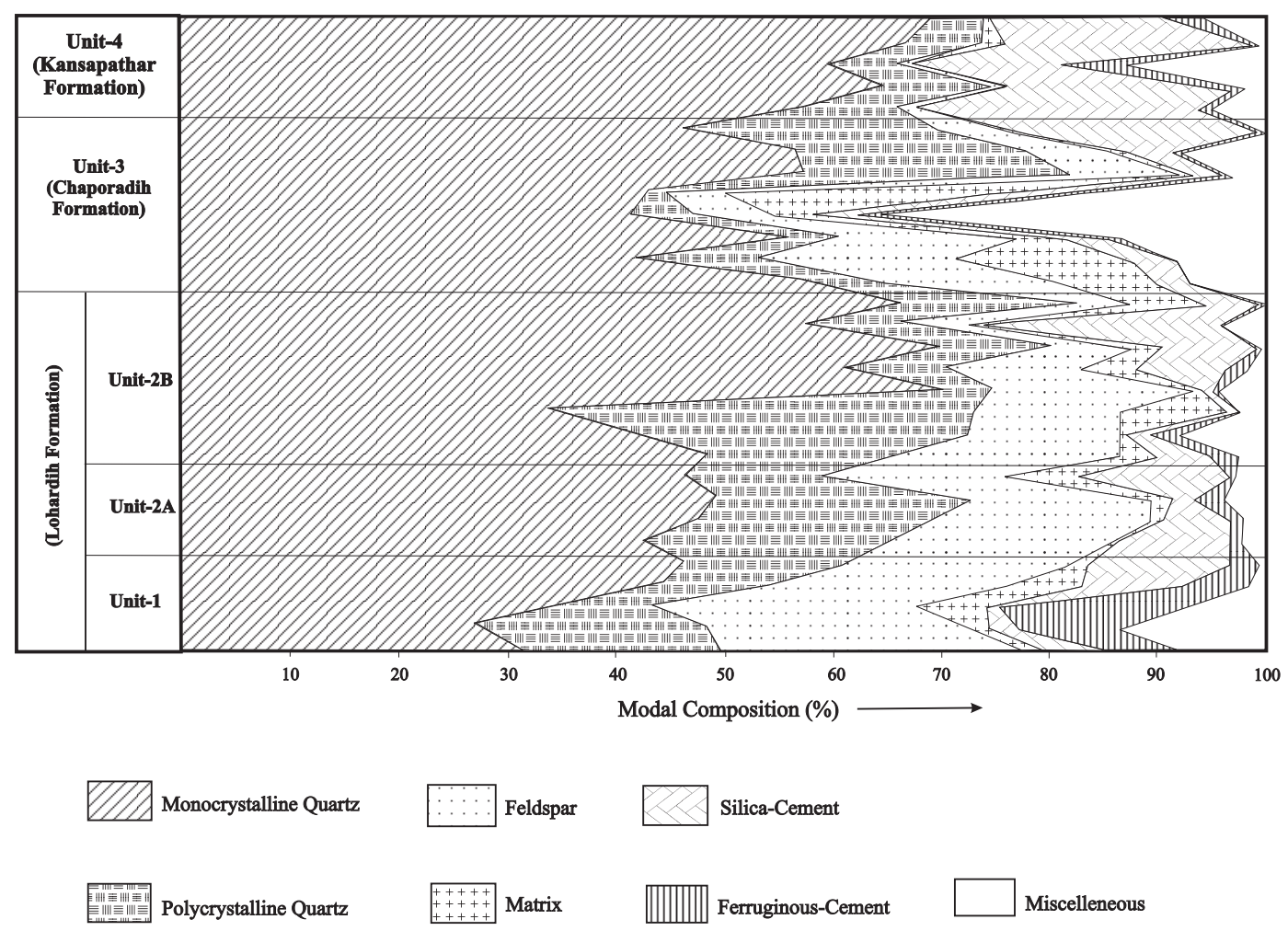

Figure 3. Variation of modal mineralogical composition of sandstone samples of the Chandarpur Group of the Chattisgarh Supergroup along a vertical profile.

GRAIN SIZE

SORTING

ROUNDNESS

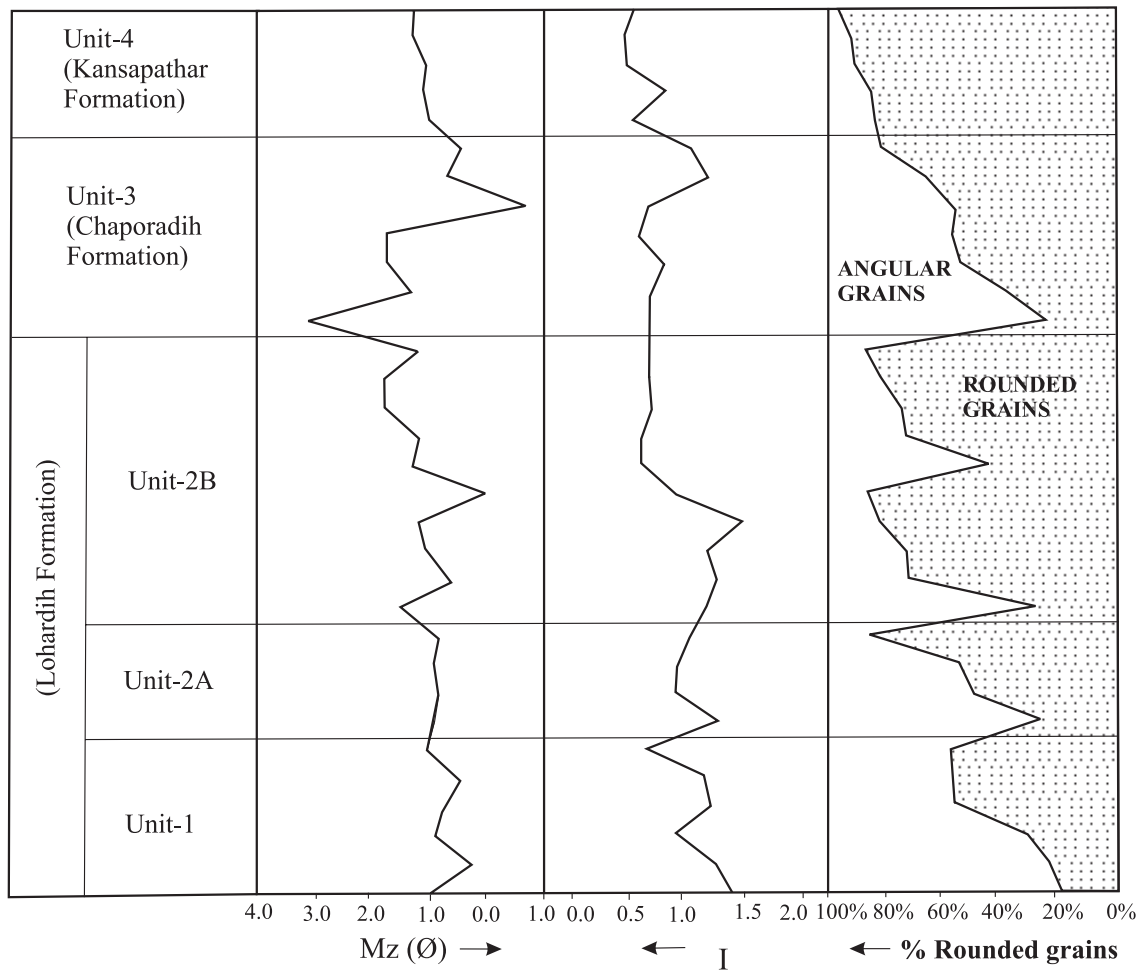

Figure 4. Variation of textural components of the sandstone samples of the Chandarpur Group of the Chattisgarh Supergroup along a hypothetical vertical profile section around Panduka, Chattisgarh, India. 


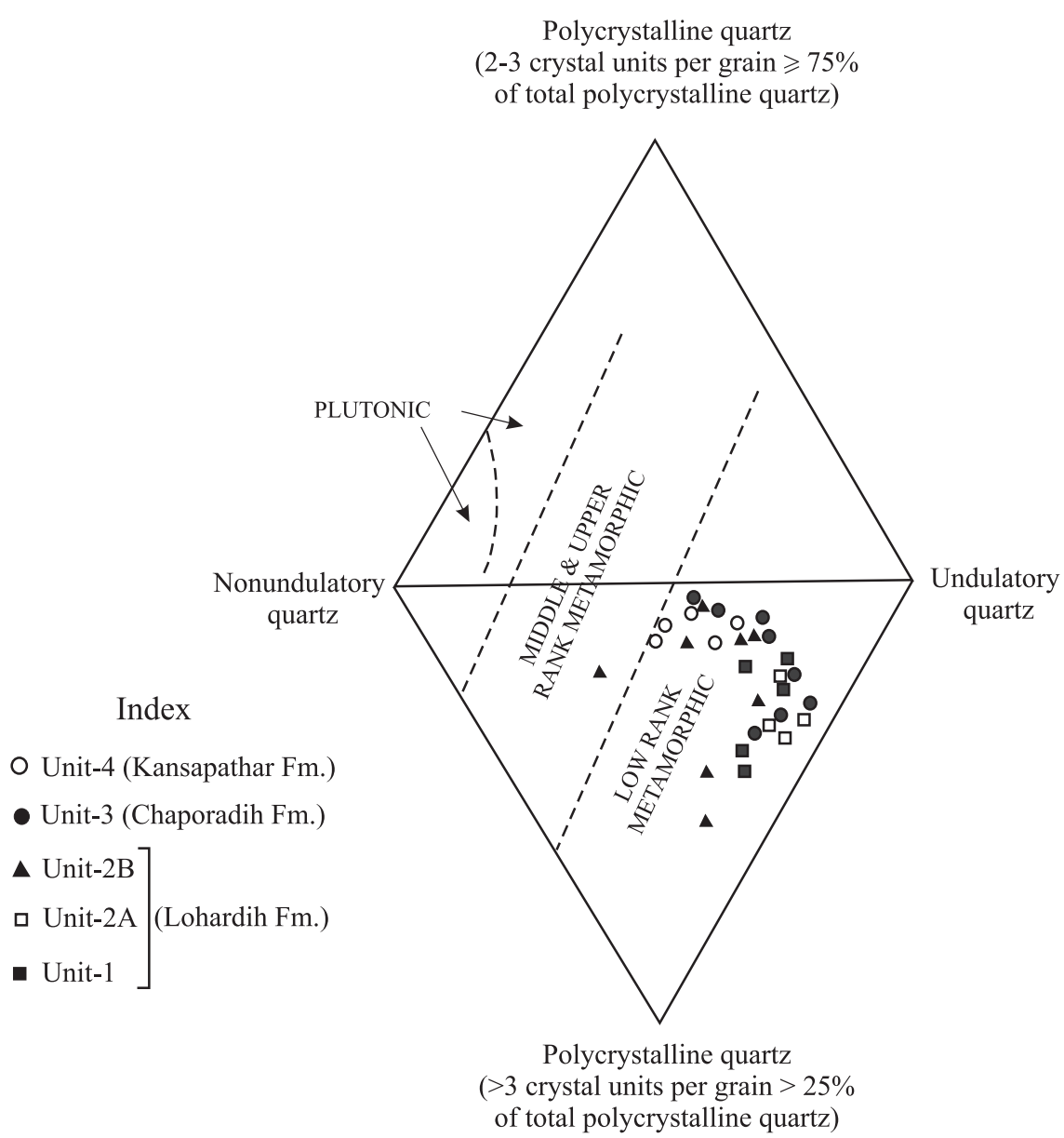

Figure 5. Diamond diagram plot, after Basu et al (1975) of sandstone samples of the Chandarpur Group.

The sandstone in the lower part (unit-2A) is poorly sorted, and shows bimodal grain size distribution with a very coarse sand to granule mode and a fine to very fine sand mode (figure 11). By contrast, the sandstone in the upper part (unit-2B) is generally medium- to fine-grained and is moderately well sorted (table 4). Most samples of $2 \mathrm{~A}$ and 2B show coexistence of angular and rounded grains, with higher proportion of angular grains in the lower part of the unit. A few samples from $2 \mathrm{~A}$, however, are composed entirely of rounded grains irrespective of grain size.

The framework components are dominated by monocrystalline and polycrystalline quartz, orthoclase and microcline (tables 2 and 3). Granite fragment, perthite, claystone-siltstone fragment, detrital chert, volcanic rock fragment, glauconite pellet, mica, opaque and heavy minerals occur in subordinate amount. Monocrystalline undulatory quartz, polycrystalline quartz and monocrystalline non-undulatory quartz occur in decreasing order of abundance in the lower part of the unit. The frequency of polycrystalline quartz grains decreases rapidly upwards. The coarser mode of the bimodal samples is dominated by polycrystalline quartz, whereas the finer mode consists only of monocrystalline quartz (figure 11). Fresh and partly to extensively altered feldspar grains coexist in a few thin sections, though in many samples almost all grains are heavily altered. Heavy minerals, mostly zircon and sphene are very common. The sandstones are generally matrix-free, with a few exceptions, where matrix may range up to $10 \%$ (table 2). Localised patches of clay epimatrix (Dickinson 1970) along with relicts of feldspar occur in a few thin sections. Authigenic quartz is the dominant cement and varies from $<1-23 \%$. Contacts between adjacent overgrown parts are usually straight. Authigenic feldspar overgrowths around detrital feldspar grains occur in traces.

\subsubsection{Interpretation}

Local abundance of well rounded grains irrespective of their size in mineralogically immature fluvial sandstones in the lower part of unit-2 appears to be anomalous, and may be related to strong wind abrasion within the alluvial depositional system. 


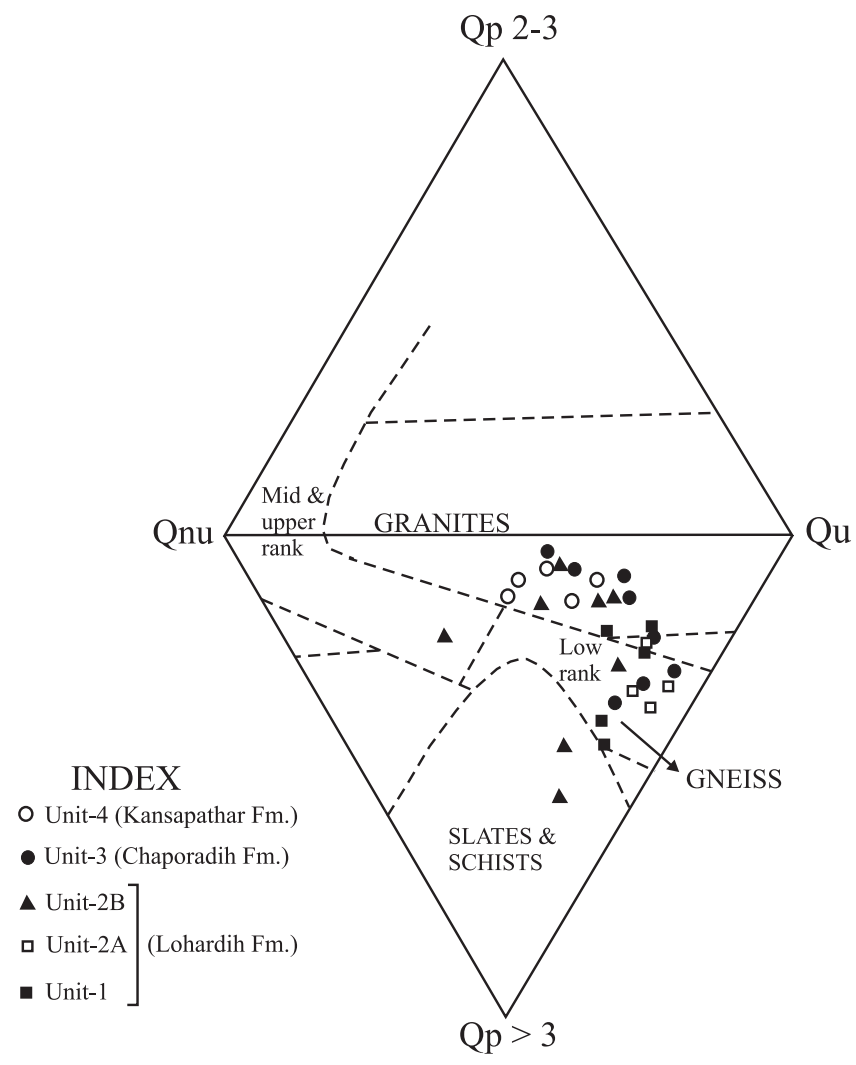

Figure 6. Diamond diagram plot, after Tortosa et al (1991) of the same set of sandstone samples used in figure 5 .

Bimodal size distribution in fluvial deposits commonly results from infiltration and entrapment of finer mode within the voids of the coarser primary framework (Moss 1962, 1963; Visher 1969; Pettijohn 1984). The bimodality discussed here, however, occurs entirely within the sand range $(0.1-2.0 \mathrm{~mm})$, and may indicate selective eolian deflation of the fine sand fraction $(0.1-0.3 \mathrm{~mm})$ leaving behind both very fine and coarser material (Folk 1968).

The abundance of non-undulatory monocrystalline quartz suggests plutonic provenance for these sandstones (Blatt 1967; Basu et al 1975; Suttner et al 1981; Tortosa et al 1991), though it may also be a reflection of grain size. It is noted here that the proportion of polycrystalline quartz is directly proportional to the grain size (also see Basu et al 1975; Basu 1976; Harrell and Blatt 1978; Suttner et al 1981; Decker and Helmold 1985; Tortosa et al 1991). Presence of zircon and sphene also weigh in favour of plutonic granitic provenance (Basu 1976). Occurrence of highly to almost completely altered feldspar grains and local occurrences of clay patches with relicts of feldspar indicate diagenetic derivation of clay from in situ alteration of feldspar. Well developed quartz overgrowths around well rounded quartz grains together with excellent sorting in a few samples of this unit point to large pre-cement porosity. High pre-cement porosity is also indicated by the development of straight long common edge between two overgrown parts.

\subsection{Chaporadih Formation (unit-3)}

Mudstone dominated Chaporadih Formation contains a few storm deposited isolated lensoid bodies of coarse-grained sandstones and thin sheets of hummocky cross-stratified fine-grained sandstone (figure 12). The sandstones are all subarkosic (tables 2 and 3 ; figure 2), poorly to moderately well sorted with grain size varying from granule-bearing very coarse sand to fine sand (table 4). Many samples consist of both well rounded and angular

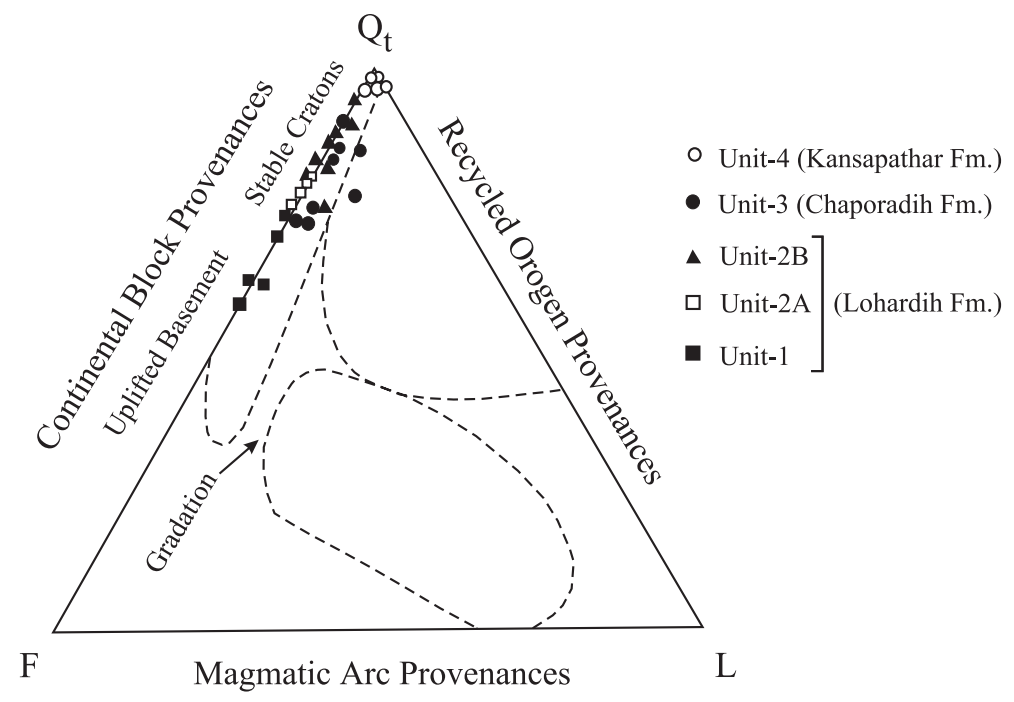

Figure 7. $\mathrm{Q}_{\mathrm{t}} \mathrm{FL}$ triangular plot, after Dickinson and Suczek (1979) of sandstone samples of the Chandarpur Group. 


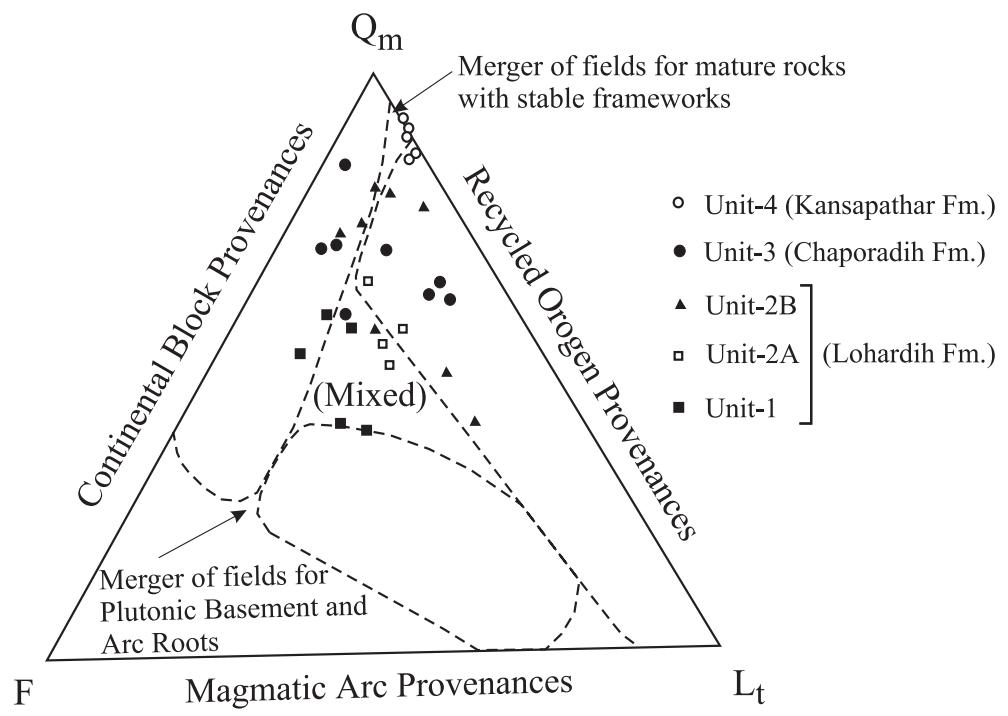

Figure 8. $\mathrm{Q}_{\mathrm{m}} \mathrm{FL}_{\mathrm{t}}$ triangular plot, after Dickinson and Suczek (1979) of the same set of sandstone samples used in figure 7.

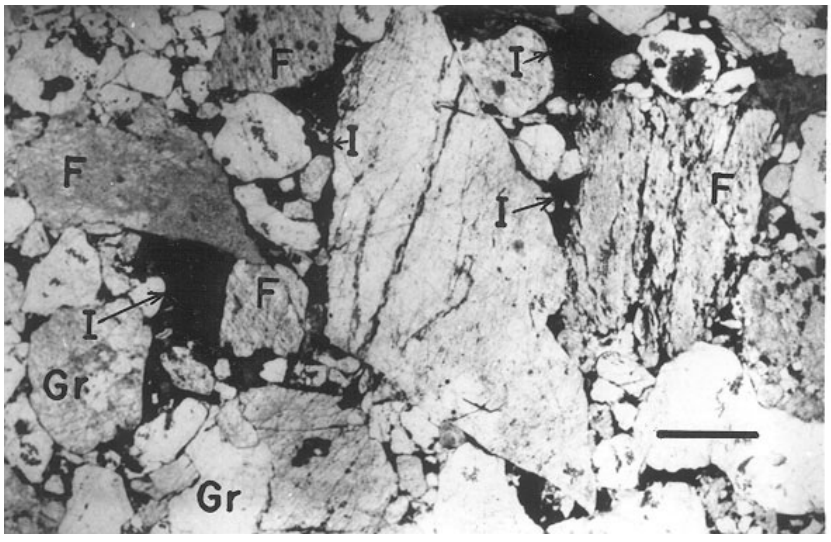

Figure 9. Photomicrograph showing a poorly sorted arkose of unit-1 (Lohardih Formation). Note the presence of very angular grains, fractured and weathered feldspar (F), abundant iron-oxide (I) in interstitial spaces and granite rock fragments (Gr) having quartz crystals within larger microcline (plane polarised light). Scale bar $=1.0 \mathrm{~mm}$.

grains (table 4), though a few coarse-grained sandstones consist exclusively of well rounded to subrounded grains of quartz and feldspar. Samples from several beds contain angular cleavage blocks of feldspar (figure 13). Coexistence of fresh and altered feldspar grains is very common. A few samples, however, contain only rounded grains of fresh feldspar (dominantly microcline), whereas few others contain only altered and iron-stained angular feldspar grains (figure 13). The sandstones are characterised by an abundance of claystone/siltstone clasts that may constitute up to $35 \%$ of the rock. At places, these are distorted into irregular shapes (figure 14). Glauconite pellets are very common (up to $11 \%$ ). The sandstones are rich in clay-silt matrix which vary from

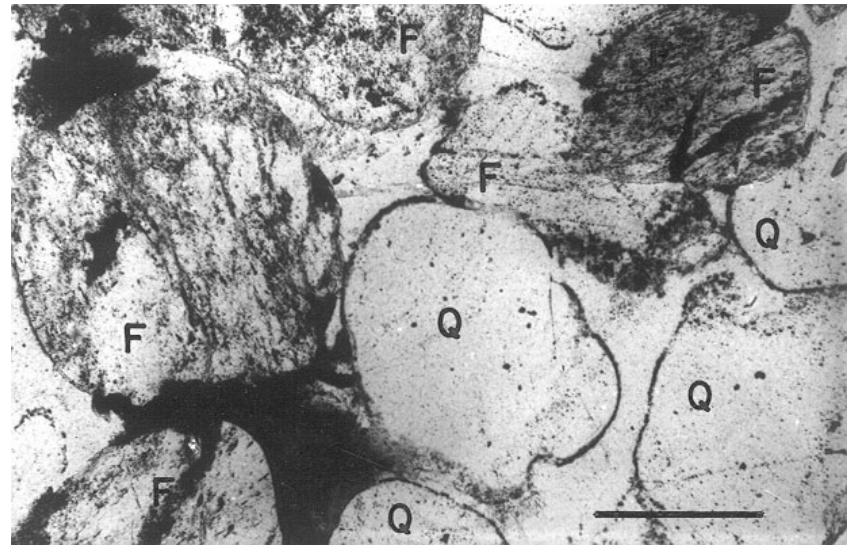

Figure 10. Photomicrograph of a medium-grained arkose from the upper level of unit-1 (Lohardih Formation) showing rounded quartz (Q) and orthoclase feldspar (F) grains. Note the presence of abundant silica-cement, thin rims of iron-oxide surrounding the quartz grains and partly weathered orthoclase grains (plane polarised light). Scale bar $=0.25 \mathrm{~mm}$.

$<1-24 \%$ (table 2). The quartz cement forms overgrowths around detrital quartz grains, particularly in matrix-free sandstones, and ranges up to $23 \%$.

\subsubsection{Interpretation}

The well rounded grains in mature coarse-grained sandstones may indicate prolonged abrasion in wave-dominated marine environment. However, rounded grains of feldspars in coarse-grained, matrix-free sandstones within mudstone unit militates against strong and protracted wave reworking (Chaudhuri 1977). Coexistence of well rounded quartz and feldspar grains, on the other hand, points to eolian reworking, and incorporation of 


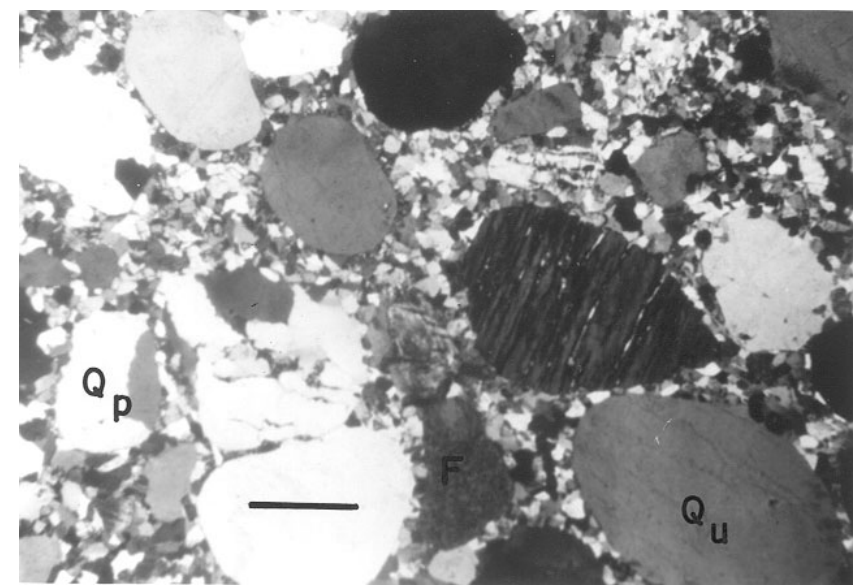

Figure 11. Photomicrograph of a subarkose from unit-2A (Lohardih Formation) showing bimodal grain size distribution defined by rounded coarser grains and angular finer grains. Note the presence of well rounded feldspars (F), polycrystalline quartz (Qp) (2-3 crystals per grain), and undulose quartz $(\mathrm{Qu})$ grains within the coarser fraction (cross polarised light). Scale bar $=1.2 \mathrm{~mm}$.

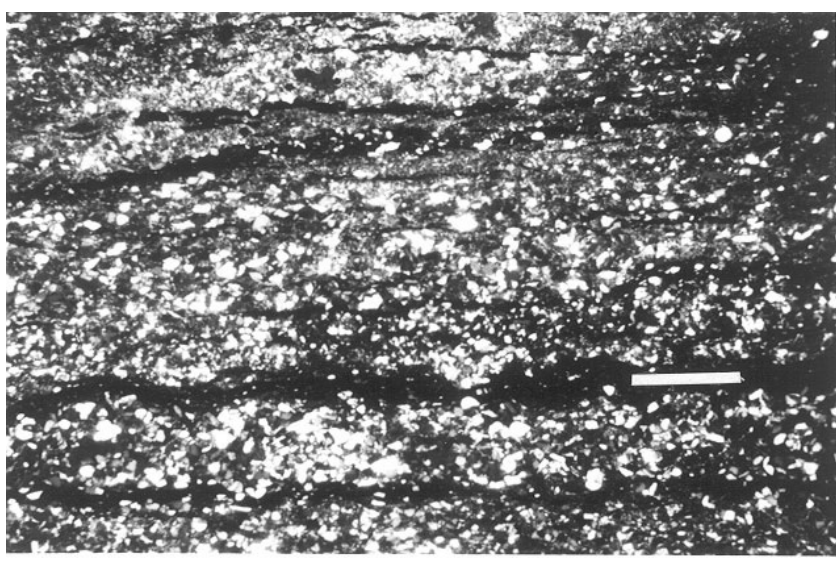

Figure 12. Photomicrograph of a fine-grained sandstone from unit-3 (Chaporadih Formation) showing continuous to discontinuous iron-oxide rich laminae. Note wavy laminations at places and presence of angular to subrounded quartz and feldspar grains (cross polarised light). Scale bar $=1.0 \mathrm{~mm}$.

mature sands within the muddy shelf by storm. The clay patches with relicts of feldspar suggest significant in situ alteration of feldspar grains. The claystone/siltstone fragments are intrabasinal and were generated as rip-up clasts by storm surges during sea level fall (Allen 1980; Garzanti 1991; Zuffa et al 1995).

\subsection{Kansapathar Formation: Purple quartzarenite (unit-4)}

The upper shoreface sandstones of the Kansapathar Formation are all medium- to coarse-grained

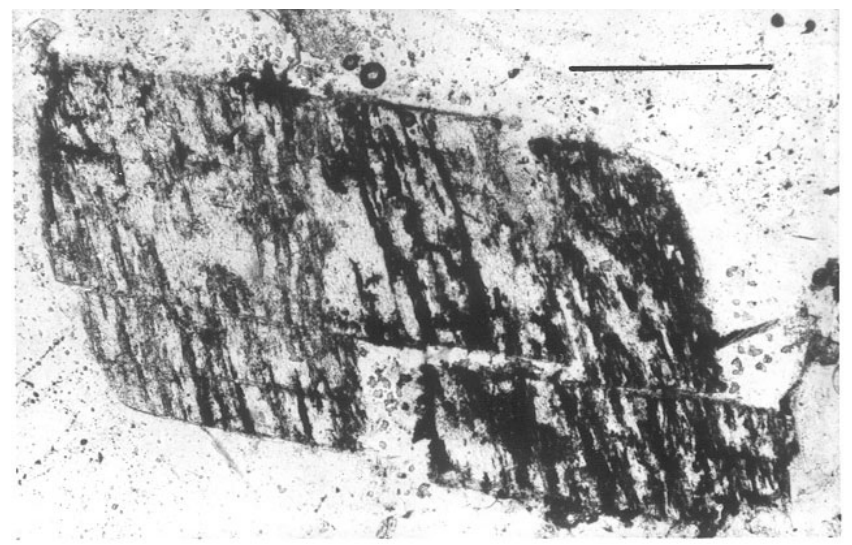

Figure 13. Photomicrograph showing an altered and iron-oxide stained angular feldspar grain in subarkose of unit-3, Chaporadih Formation (plane polarised light). Scale bar $=0.30 \mathrm{~mm}$.

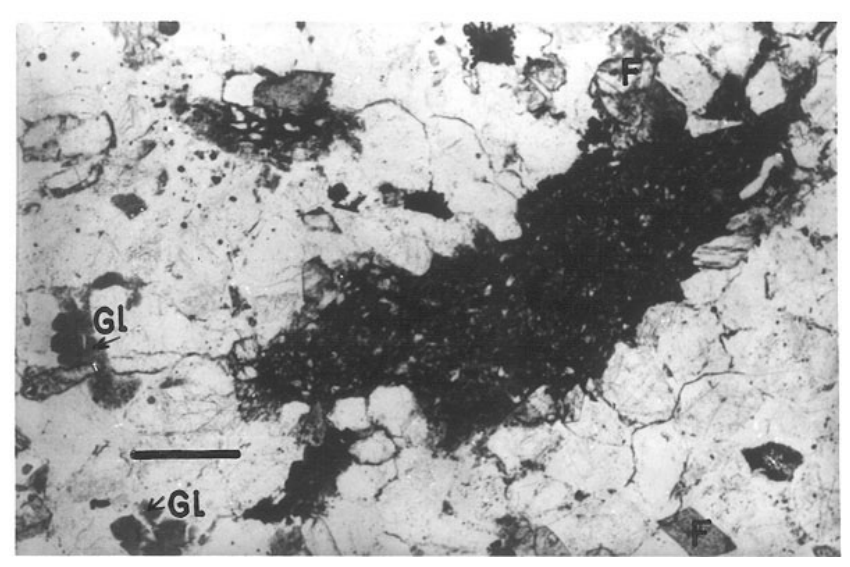

Figure 14. Photomicrograph of a large claystone/siltstone fragment in medium-grained subarkose of unit-3 (Chaporadih Formation). Note the indentation of the grain boundary of the large claystone-siltstone fragment by surrounding smaller grains, and presence of smaller glauconite (Gl) and angular feldspar (F) grains (plane polarised light). Scale bar $=0.45 \mathrm{~mm}$.

supermature quartzarenite (tables 2 and 3; figure 2) characterised by high grain rounding and sorting (table 4) and high pre-cement porosity (figure 15). The ubiquitous presence of a large number of rounded $(42 \%)$ and well rounded grains $(30 \%)$ (figure 17; roundness measured by visual comparison with Power's scale, 1953) in the sandstones is striking.

The framework grains are composed dominantly of mono- and polycrystalline quartz with a subordinate amount of glauconitic pellets (figure 16). Stretched metamorphic quartz is very common among the polycrystalline variety. Glauconitic pellets appear as authigenic, formed after detrital feldspar grains. These are generally altered and are often smeared with iron-oxide. The sandstones 


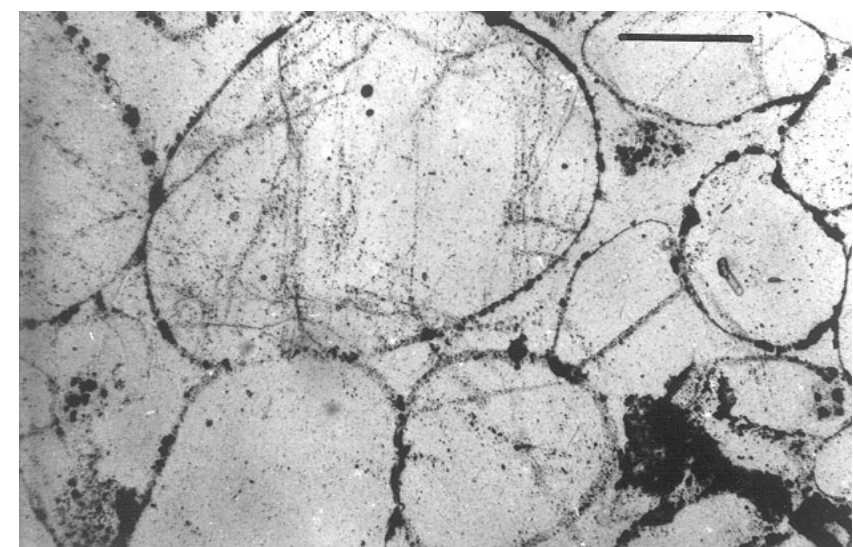

Figure 15. Photomicrograph of a clean medium-grained quartzarenite of unit-4 (Kansapathar Formation) showing thin semicontinuous rims of iron-oxide around well rounded quartz grains with point contacts among them, dominance of quartz cement and minor amount of iron-oxide cement in intergranular spaces. Note the retention of iron-oxides at the grain contacts (plane polarised light). Scale bar $=0.20 \mathrm{~mm}$.

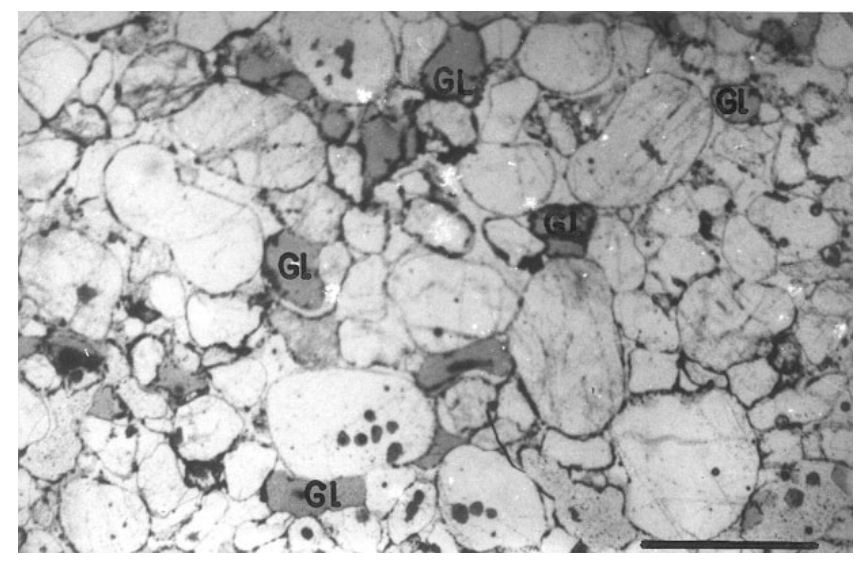

Figure 16. Photomicrograph of a medium-grained quartzarenite of unit-4 (Kansapathar Formation) showing rounded grains, moderate sorting, thin rims of iron-oxide coatings, point contacts of grains, and glauconite grains (Gl) (plane polarised light). Scale bar $=0.80 \mathrm{~mm}$.

are generally devoid of matrix, and intergranular spaces are entirely filled up by quartz cement which constitutes about $15-27 \%$ (figure 15). The authigenic silica rims are in general separated from the detrital cores by thin sheaths of ironoxide (figure 15). Iron-oxide occurs as grain coating (figures 15 and 16), and only rarely as inclusions within and outside the overgrown rims of quartz cement (figure 15). The purple colour, a striking feature of the sandstone, owes its origin to ferruginous cement.

\subsubsection{Interpretation}

The absence of any abraded, rounded, double or interpenetrating overgrowth weighs in favour

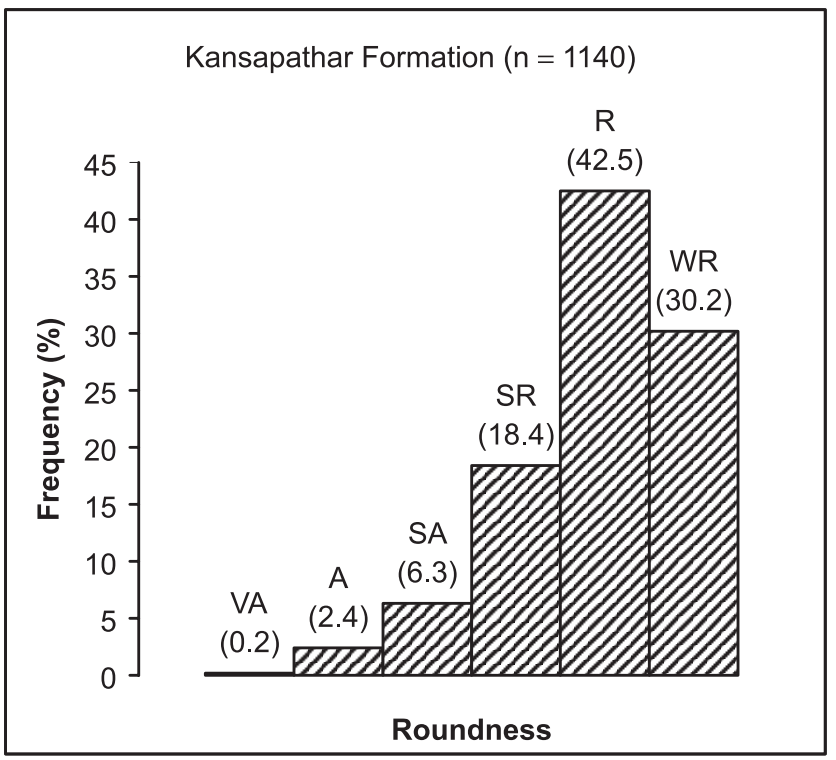

Figure 17. Histogram showing grain-roundness distribution of sandstone samples of the Kansapathar Formation $(\mathrm{VA}=$ Very angular, $\mathrm{A}=$ Angular, $\mathrm{SA}=$ Subangular, $\mathrm{SR}=$ Subrounded, $\mathrm{R}=$ Rounded, $\mathrm{WR}=$ Well rounded).

of first-cycle origin of the quartzarenites (Jones 1972; Chaudhuri 1977; Sanderson 1984). As the first-cycle quartz sands are difficult to produce, especially in the Proterozoic before the appearance of vascular land plants (Dott 2003; Basu, written communication), the supermaturity of the Kansapathar sandstone is enigmatic. The dominance of only mono- and polycrystalline quartz and the presence of glauconite $(<1-4 \%)$ do not suggest diagenetic origin of the quartzarenites (McBride 1987). The high mineralogical maturity may be attributed to protracted high energy marine reworking in littoral, beach or upper shoreface where the detritus could be winnowed several times before deposition (Cotter 1983). However, effective grain rounding by marine surf action is doubtful (Pettijohn et al 1987). High percentage of rounded and well rounded grains (figure 17) in these sandstones may be caused most effectively by eolian processes in a single cycle of sedimentation (Folk 1968; Chaudhuri 1977). The mature detritus formed in coastal environments were repeatedly exposed when the grains were further rounded by intense eolian reworking. The iron-oxide coating around well rounded grains strongly suggests that precipitation of iron-oxide post-dated grain rounding, and represents the earliest authigenic event. The thin coats of iron-oxide could be achieved in a desert-like hot-dry condition (Folk 1968, 1976) in extensive coastal dunes on the exposed upper part of the shelf (Walker 1967). In the possible scenario of coastal dune environment visualised here, the upper part of the dunes were very hot and 
dry, whereas their interiors remained damp/humid enough to promote reddening (see, Folk 1976). The iron-oxide coated grains were eventually transported by storms and tides to be deposited and buried in the shoreface environment (cf. Shinn 1973) to form silica cemented quartzarenites.

\section{Vertical changes in composition and textural attributes}

The compositional and textural attributes plotted in figures 3 and 4 exhibit the occurrence of two fining-upward cycles. Cycle- 1 starts from the base of the succession and ends at the mudstone and fine-grained sandstone dominated lower part of the Chaporadih Formation. Cycle-2 begins from the coarse-grained sandstones in the upper part of the Chaporadih Formation and follows up to the sandstones of the Kansapathar Formation.

\subsection{Cycle-1}

The sandstones at the base of this cycle are highly feldspathic, coarse-grained and have high matrix content, and are marked by highly weathered grains, low quartz cement and high source-derived iron-oxide content. The grain size, feldspar content, frequency of weathered grains and source-derived iron show a distinctly declining trend up to the top of the cycle (figure 3). The decreasing feldspar content is accompanied by corresponding increase in the framework quartz as well as quartz cement. Monocrystalline and polycrystalline quartz exhibit a complementary variation in their concentration. The highest concentration of polycrystalline quartz occurs in the coarse-grained sandstones at the lower part of the cycle (unit-1: alluvial fan and unit-2A: braided fluvial deposits) and continues to decline upwards. A few beds within the fluvial interval (unit-2A) show high content of quartz cement (up to about 14\%) where the rocks are marked by very high grain roundness and strong bimodality in grain size. The shallow subtidal barinterbar and tidal flat deposits (unit-2B) immediately above the fluvial deposits show considerable bed-to-bed variation in both quartz cement and matrix content. The quartz cement increases quite distinctly at the upper most part of unit-2B where the sandstones are quartzose and exhibit signatures of deposition as shoreface shoal bars.

The sandstones at the basal part of the cycle are marked by poor sorting and high frequency of very angular grains with tongues/apophyses and sharp edges (figures 4 and 9). The frequency of well rounded grains as well as size sorting of grains increase upwards. The braided fluvial sandstones overlying the alluvial fan deposits are also poorly sorted and show high abundance of angular grains though many beds of the fluvial sandstones show a population of rounded to well rounded grains and bimodality in grain size distribution. Broad fluctuations in grain size and in the ratio of rounded and angular grains have been noted throughout the subtidal to intertidal deposits that overlie fluvial deposits. The sorting values remain more or less steady in the upper part of the shallow marine deposits. The overlying muddy shelf deposits of the Chaporadih Formation at the top of the cycle show a significant inflection in the abundance of angular grains (up to $76 \%$ ) together with a sharp decrease in grain size $\left(\mathrm{M}_{\mathrm{z}} \approx 3.1 \phi\right)$ (table 4$)$.

\subsection{Cycle-2}

The feldspar, polycrystalline quartz, iron-oxide impregnated grains, and matrix content (max. $24 \%$ ), as well as frequency of angular grains and grain size sharply rise in the coarse-grained storm laid sandstones in the lower part of cycle-2. The frequency of feldspar, polycrystalline quartz, matrix content and also the angular grains gradually decline upwards, and at the top of the Kansapathar Formation (unit-4) the rock becomes a supermature quartzarenite with high amount of quartz cement (up to 27\%) and iron-oxide cement. The frequency of rounded grains also increases steadily from the base to the top of the cycle (figure 4). The sorting value continues to fluctuate in the lower part of the topmost quartzarenite unit, and subsequently improves and becomes steady in the upper part.

\subsection{Interpretation}

The decreasing trend in feldspar content, frequency of weathered grains and grain size from base upwards indicates that the initial stage of each cycle was marked by high relief in provenance, high rate of sediment generation, rapid transport down a high gradient and rapid deposition. The source contained weathered, iron-oxide impregnated regolith as well as freshly exposed blocks of basement crystalline rocks, and was very close to the depocentre. Increasing frequency of fresh feldspar grains up the cycles at the expense of altered feldspar grains points to gradual removal of weathered crust in the provenance, peneplanation and unroofing of fresh bed rocks with time. The decreasing value of the polycrystalline/ monocrystalline quartz ratio from base upwards, however, may be controlled by mechanical abrasion, and depletion of polycrystalline grains in medium-grained wave reworked sandstones may be related to mechanical disintegration of the grains into their subgrains. 
The textural and compositional heterogeneity in the upper part of the Lohardih Formation (unit2B) may be related to a heterogeneous hydrodynamic regime which operated on a very local scale. The wave reworked bar sandstones are nearly matrix-free and are composed of well rounded grains with abundant quartz overgrowth. By contrast, the low energy deposits formed between bars are relatively finer grained, and are dominated by angular grains and high matrix. The relationship indicates that reworking in the coastal marine environments did not uniformly enhance the maturity of the detritus. It only segregated sediments into fractions to be deposited in locally variable hydrodynamic environments. The frequency of rounded grains in the shoal-bar sandstones is relatively low as compared to that in the underlying fluvial sandstones (unit-2A). The data appears to be anomalous, but points to eolian rounding of grains in exposed alluvial plains. The data further suggests that grains were not significantly rounded by mechanical abrasion in coastal marine environments. The dominance of well rounded grains at certain levels of the alluvial fan and/or braided stream deposits points to intense eolian activity on extensive, barren Proterozoic landscape and climatic excursion towards higher aridity.

The petrographic attributes of sediments at the base of the fining-upward cycles strongly suggest that sedimentation in both the cycles followed tectonic uplift of basement block. The tectonic uplift at the basin margin created accommodation space for rapidly deposited coarse-grained sediments in multiple fining-upward retrogradational succession. In cycle- 1 the peak of retrogradation/transgression is represented by the mudstone dominated lower part of the Chaporadih Formation. The base of cycle- 2 may be inferred as a surface of forced regression, and correlative of a basin margin unconformity. The occurrence of altered and iron-oxide impregnated, regolithic material at the base of each cycle suggest hiatus and development of weathered crust in the provenance.

\section{Palaeoclimatic implications}

Abundance of iron-oxide and iron-oxide impregnated grains, such as feldspar and biotite, and altered feldspar in the immature sediments at the base of each cycle collectively suggest a humid climatic condition (Krynine 1949; Hubert 1960; Van Houten 1972, 1973; Turner 1980). However, red beds are not unequivocal indicator of palaeoclimate (Berner 1969) and iron-oxide may also form post-depositionally in hot, arid or semiarid climate
(Walker 1967; Folk 1968). Alteration of feldpars is also reported from both humid and dry climates (Basu 1976). The inference of humid climatic condition has been preferred on the basis of textural attributes. Abundance of well rounded grains, specially well rounded fresh feldspar grains, high degree of sorting or bimodal roundness distribution are the hallmark of intense wind activity and high aridity. Concentration of highly rounded grains at a few stratigraphic levels within the fan and braided fluvial deposits of the Lohardih Formation indicates episodic climatic excursion to high aridity and development of 'condensed zones' with low or almost 'no' deposition over stable land surfaces. Higher incidence of well rounded grains in the $\mathrm{flu}-$ vial deposits indicates that much of the sands was inherited from the fan deposits, and was further reworked by eolian processes on large exposed surfaces of braid plains. In the barren Proterozoic landscape wind action was likely to be very intense and rounded grains had been produced all around. The blown sands were incorporated in laterally migrating braided streams and were mixed-up with water-borne detritus. The climate appears to have been characterised by alternating humid and dry spells. A hot desertic climate developed during the Kansapathar sedimentation where abundant well rounded detritus were generated and were coated by iron-oxide in sandflats and dunes. A supermature red bed deposit developed in a hot, arid climatic regime.

\section{Clues for provenance}

\subsection{Source area lithology}

Detrital quartz grains are the most abundant constituent in the cratonic sandy deposits (Krynine 1948; Folk 1951, 1980; Basu 1985). The degree of undulosity of monocrystalline quartz grains, and number of subgrains within the polycrystalline quartz grains can be a useful discriminant of different kinds of source rocks (Basu et al 1975; Basu 1985).

Polycrystalline quartz grains with 2-3 subgrains never exceeds or equals $75 \%$ of the total polycrystalline quartz grains in the all studied samples, and all the data points fall within the lower triangle of the diamond diagram (figures 5 and 6). With higher undulatory/non-undulatory monocrystalline quartz ratio, most of them fall within the low-rank metamorphic field in the diagrams of both Basu et al (1975) and Tortosa et al (1991). Low-rank metamorphic source includes slate/schists or other supracrustals which have undergone low grade metamorphism in chlorite to biotite zone (Basu et al 1975), or a granite-gneissic 
source which had undergone low grade of metamorphism or had a formation temperature range of about $450^{\circ} \mathrm{C}$ (Tortosa et al 1991). Dominance of orthoclase and microcline, frequent occurrence of granite rock fragments and presence of grains with perthitic intergrowth in coarse-grained sandstones at the lower part of cycle- 1 and cycle- 2 indicate that the detritus were derived from granitic and low-rank gneissic rocks rather than from slates and low grade schists.

Abundance of 'granite wash'-like arkose at the base of the Lohardih Formation immediately overlying the basement strengthen the conclusion that bulk of the clastics was derived from underlying granite-gneissic basement. Stretched metamorphic polycrystalline quartz grains occur in minor amount, and point to the presence of enclaves of metamorphic rocks within the granite-gneissic provenance. The presence of sedimentary, metamorphic and volcanic rock fragments in trace amount indicates that a minor part of the detritus was derived from an older volcano-sedimentary succession in the source area.

\subsection{Tectonic setting of the provenance}

Dickinson and Suczek (1979) and Dickinson et al (1983) did not include the Precambrian suites in their provenance analysis because of uncertainty of plate tectonics in the Precambrian. However, an attempt has been made here to analyze the tectonic setting of the provenance in view of the fact that the Indian craton is a collage of several Archaean cratonic nuclei and mobile belts (Acharyya 1997).

The procedure suggested by Dickinson and Suczek (1979) has been used though, a few departures had to be made for defining different elements for the modal analysis. The siltstone/ mudstone fragments that are traceable to intrabasinal sources, have been ignored. The metasedimentary fragments such as argillite and phyllite showing definite signatures of metamorphism are of extrabasinal parentage and have been included within ' $\mathrm{L}_{\mathrm{s}}$ '. Detrital chert and polycrystalline quartz grains have been counted separately in view of their distinctly different origin, and lower mechanical stability of polycrystalline quartz compared to chert (Blatt 1967). The grains with majority of the subgrains less than $30-20 \mu \mathrm{m}$ in size have been considered as chert (Pettijohn et al 1987). The grains where the subgrains are larger than 30-20 $\mu \mathrm{m}$ have been considered as polycrystalline quartz (Basu et al 1975; Young 1976; Harrell and Blatt 1978; Pettijohn et al 1987; Folk 1980). The definition of polycrystalline quartz used here is different from the one used by Dickinson (1985) who defined only those grains with subgrains smaller than $62.5 \mu \mathrm{m}$ as polycrystalline quartz. Because of the above modification, the $\mathrm{Q}_{\mathrm{p}}$ content in the present analysis has increased significantly. Incorporation of $\mathrm{Q}_{\mathrm{p}}$ into the $\mathrm{L}_{\mathrm{t}}$ pole, however, has resulted in significant shift of the plots towards the $\mathrm{L}_{\mathrm{t}}$ pole in the $\mathrm{Q}_{\mathrm{m}} \mathrm{FL}_{\mathrm{t}}$ diagram.

The practice of counting feldspar crystals within granite rock fragments as feldspar grains (Dickinson 1970) has also not been followed in the present analysis because of specific significance of granitic rock fragments (see Suttner and Basu 1985; Decker and Helmold 1985). This departure, however, does not affect the diagrams, because feldspar grains and granite rock fragments together constitute the ' $\mathrm{F}$ ' pole.

In the $\mathrm{Q}_{\mathrm{m}} \mathrm{FL}_{\mathrm{t}}$ diagram with the field boundaries showing different tectonic setting (figure 8), nearly equal number of data points are plotted in the continental block and recycled orogen provenance fields, with a few points falling in the mixed fields. Occurrence of several points in the recycled orogen provinces appears to have been caused by the modified classification of polycrystalline quartz $\left(Q_{p}\right)$ which has resulted in significant shift of the data points towards $\mathrm{L}_{\mathrm{t}}$ pole.

In the $\mathrm{Q}_{\mathrm{t}} \mathrm{FL}$ plot, on the other hand, nearly all the data points fall within the continental block tectonic field (figure 7). The arkosic alluvial fan sandstone from the basal part of the Lohardih Formation occur in the uplifted basement provenances. Most of the subarkosic rocks of the braided fluvial and the samples from the shallow marine sandstones of the Lohardih Formation and the Chaporadih Formation occur in the stable craton field (figure 7). The supernature rocks of the Kansapathar Formation occur in the stable craton field very close to $\mathrm{Q}_{\mathrm{t}}$ pole, i.e., craton interior field (figure 7).

The general petrographic attributes also suggest that the arkosic sandstones of the lowermost unit were derived from an uplifted basement province. The occurrence of braided fluvial sandstones and the shallow marine subarkosic sandstones in the stable craton field appears to reflect different stages of peneplanation in the provenance. The occurrence of supermature quartzose sandstones of the Kansapathar Formation in the stable craton/craton interior field may also reflect peneplanation of the source terrain. The decreasing feldspar content and decreasing grain size in the sandstones also suggest peneplanation of stable cratonic provenance, though transition from immature to mature or supermature rocks was achieved by prolonged environmentally controlled differentiation. The supermature sandstones of the Kansapathar Formation are inferred to be of first cycle-origin. 


\section{Conclusion}

The siliciclastic succession of the Chandarpur Group of the Late Proterozoic Chattisgarh Supergroup occurs in two fining-upward cycles; each cycle starts with coarse-grained feldspathic sandstones, becomes finer and more matured upwards, both mineralogically and texturally. Provenance analysis indicates that the sediments were derived from low grade granites and granite-gneisses of continental block tectonic setting. The coarsegrained immature arkosic to subarkosic sandstones at the base of each cycle were derived from uplifted basement blocks, whereas relatively mature sandstones in the upper part of the cycles were derived from stable craton or craton interior fields. Analysis of the petrographic attributes indicates that increasing maturity of the sediments was related to peneplanation in the source, indicating increasing stability of the cratonic block, as well as to environmental and climatological differentiation. The uppermost unit of the succession, a supermature purple quartzarenite was of climatically forced first-cycle origin. Strong eolian reworking, under arid to semi-arid climatic regime, on barren Proterozoic land surface strongly modified mineralogical composition and textural attributes of the detritus.

The fining-upward cycles were generated by tectonic uplift of cratonic blocks in the provenance that supplied highly altered and iron-impregnated detritus from the weathered crust and freshly exposed blocks. Sediments were eroded at a high rate from the high relief provenance, and were rapidly deposited creating multiple fining upward succession. With continued un-roofing and peneplanation in the provenance, rate of erosion slowed down and sediment calibre became finer, and the rate of sediment influx was out paced by base level change and transgression. The basal surface of the second fining-up cycle represents tectonic rejuvenation, forced regression, and a possible basinward surface of conformity to a basin margin unconformity.

The immature sediments at the base of each cycle with abundant source derived iron-oxide cement, highly altered and iron-oxide impregnated feldspar and biotite grains collectively point to prevalence of humid climate when the weathered crust developed. Climatic shift towards higher aridity with time is indicated by the occurrence of highly rounded grains of fresh feldspar within fan and fluvial deposits at the lower part of the cycles. Concentration of highly rounded grains at several stratigraphic levels indicate episodic, sharp climatic excursion to aridity and development of condensed zone where loose detritus was exposed. The barren Proterozoic surface was intensely reworked and abraded by eolian processes. The supermature quartzarenite at the top of the second-cycle represents a desert-like condition where sands were rounded and coated with ironoxide in the wind flats as well as in coastal dunes. Iron-oxide formed both in humid and arid climate.

The southeasterly palaeoslope, inferred from the palaeocurrent studies, indicates that the sediments were derived mainly from the northwest of the study area, now occupied by the deeper water marine deposits of the overlying Raipur Group. Presence of a granitic/granite gneissic basement high in the northwest is visualised during the sedimentation of the Chandarpur Group. Provenance analysis also points to the absence of any high grade metamorphic rock in the provenance area. The inferred southeasterly palaeoslope, and absence of any high grade metamorphic rock in the provenance terrain of the Chandarpur sandstones indicate that the Eastern Ghats Granulite belt which skirts the eastern and southeastern margin of the Chandarpur sandstone belt (figure 1) possibly did not exist during the Chandarpur sedimentation in early Neoproterozoic time. This may support one of the prevailing concepts that the Eastern Ghats Mobile Belt was sutured with the Indian craton at the later part of the Neoproterozoic.

\section{Acknowledgements}

The work presented in this paper is a part of the author's doctoral dissertation done during 19921997 under the supervision of Prof. A K Chaudhuri and S N Sarkar at the Indian Statistical Institute, Kolkata. The author records his deep sense of gratitude to the Late Prof. S K Chanda of the Jadavpur University for his inspiring discussions and guidance during the work. Prof. Chanda taught the author the art of petrographic studies of sandstones. The present study was a part of the research programme on the Proterozoic basins of India, initiated and funded by the Indian Statistical Institute. The author also acknowledges his present employer, the Geological Survey of India for allowing him to complete the work of this paper. The manuscript was improved through encouraging and constructive comments from Prof. A Basu of Indiana University, USA and Prof. H N Bhattacharya of Presidency College, Kolkata.

\section{References}

Acharyya S K 1997 Evolutionary characters of the Gondwanic Indian Crust; Indian Minerals 51 (No. 1 \& 2) 1-24.

Allen J R L 1980 Sand waves: a model of origin and internal structure; Sedim. Geol. 26 281-328. 
Basu A 1976 Petrology of Holocene fluvial sand derived from plutonic source rocks: implications to paleoclimatic interpretation; J. Sedim. Petrol. 46 694-709.

Basu A 1985 Reading provenance from detrital quartz; In: Provenance of Arenites (ed.) G G Zuffa (Reidel Publishing Co.) Pp. 231-247.

Basu A, Young S W, Suttner L J, James W C and Mack G H 1975 Re-evaluation of the use of undulatory extinction and polycrysrtallinity in detrital quartz for provenance interpretation; J. Sedim. Petrol. 45 873-882.

Berner R A 1969 Goethite stability and the origin of red beds; Geochim. Et Cosm. Acta. 33 267-273.

Blair T C and McPherson J G 1994a Alluvial fan processes and forms; In: Geomorphology of Desert Environments (eds) A D Abrahams and A J Parsons (London: Chapman \& Hall) Pp. 354-402.

Blair T C and McPherson J G 1994b Alluvial fans and their natural distinction from rivers based on morphology, hydraulic processes, and facies assemblages; J. Sedim. Res. A64 450-489.

Blatt H 1967 Provenance determinations and recycling of sediments; J. Sedim. Petrol. 37 1031-1044.

Breyer J A and Bart H A 1978 The composition of fluvial sands in a temperate semiarid region; J. Sedim. Petrol. 48 1311-1320.

Chaudhuri A 1977 Influence of eolian processes on Precambrian sandstones of the Godavari valley, South India; Precambrian Res. 4 339-360.

Cotter E 1983 Shelf, paralic and fluvial environments and eustatic sea-level fluctuations in the origin of the Tuscarora Formation (Lower Silurian) of central Pennsylvania; J. Sedim. Petrol. 53 25-49.

Crook K A W 1968 Weathering and roundness of quartz sand grains; Sedimentology 11 171-182.

Das D P, Kundu A, Das N, Dutta D R, Kumaran K, Ramamurthy S, Thanavelu C and Rajaiya V 1992 Lithostratigraphy and sedimentation of Chattisgarh Basin; Indian Minerals 46 271-288.

Das N, Dutta D R and Das D P 2001 Proterozoic cover sediments of southeastern Chattisgarh state and adjoining part of Orissa; Geol. Surv. Ind. Spec. Publ. 55 $237-262$.

Datta B 1998 Stratigraphic and sedimentologic evolution of the Proterozoic siliciclastics in the southern part of Chattisgarh and Khariar, central India; J. Geol. Soc. India $\mathbf{5 1}$ $345-360$

Datta B, Sarkar S and Chaudhuri A K 1999 Swaley crossstratification in medium to coarse sandstone produced by oscillatory and combined flows: examples from the Proterozoic Kansapathar Formation, Chattisgarh Basin, M.P., India; Sedimentary Geology 129 51-70.

Decker J and Helmold K P 1985 The effect of grain size on detrital modes: a test of the Gazzi-Dickinson pointcounting method - Discussion; J. Sedim. Petrol. 55 618-620

Dickinson W R 1970 Interpreting detrital modes of graywacke and arkose; J. Sedim. Petrol. 40 695-707.

Dickinson W R 1985 Interpreting provenance relations from detrital modes of sandstones; In: Provenance of Arenites (ed.) G G Zuffa (Dordrecht: D. Reidel Pub. Co.) Pp. 333-362.

Dickinson W R, Beard L S, Brakenridge G R, Erjavec J L, Ferguson R C, Inman K F, Knepp R A, Lindberg F A and Ryberg P T 1983 Provenance of North American Phanerozoic sandstones in relation to tectonic setting; Geol. Soc. Am. Bull. $94222-235$.

Dickinson W R and Suczek C A 1979 Plate tectonics and sandstone compositions; Am. Ass. Petroleum Geol. Bull. $632164-2182$.
Dott R H Jr. 2003 The importance of eolian abrasion in supermature quartz sandstones and the paradox of weathering on vegetation-free landscapes; J. Geol. 111 387-405.

Folk R L 1951 Stages of textural maturity in sedimentary rocks; J. Sedim. Petrol. 21 127-130.

Folk R L 1960 Petrolgy and origin of the Tuscarora, Rose Hill, and Keefer Formations, Lower and Middle Silurian of Eastern West Virginia; J. Sedim. Petrol. 30 1-58.

Folk R L 1968 Bimodal supermature sandstones: product of the desert floor; Proc. 23rd. Intern. Geol. Cong., Prague 8 9-32.

Folk R L 1976 Reddening of desert sands: Simpson Desert, N.T., Australia; J. Sedim. Pertol. 46 604-615.

Folk R L 1980 Pertrology of Sedimentary Rocks; Hemphill Publishing Co., Austin, Texas, U.S.A, 182.

Folk R L and Ward W C 1957 Brazos River bar: A study in the significance of gain size parameters; J. Sedim. Petrol. $273-26$.

Franzinelli E and Potter P E 1983 Petrology, chemistry and texture of modern river sands, Amazon River system; J. Geology 91 23-39.

Garzanti E 1991 Non-carbonate intrabasinal grains in arenites: their recognition, significance, and relationship to eustatic cycles and tectonic setting; J. Sedim. Petrol. 61 959-975.

Gupta A 1998 Hummocky cross-stratification in the Chattisgarh Basin, M.P. and its hydraulic and bathymetric implications; J. Ind. Assoc. Sed. 17(2) 213-224.

Harrell J and Blatt H 1978 Polycrystallinity: effect on the durability of detrital quartz; J. Sedim. Petrol. 48 25-30.

Holland T H 1906 Presidential Address; Trans. Min. Met. Soc. India 117.

Hubert J F 1960 Petrology of the Fountain and Lyons Formations, Front Range, Colorado; Colorado School Mines. Quart. 55242.

Jones P C 1972 Quartzarenite and litharenite facies in the fluvial foreland deposits of the Trenchard Group (Westphalian), Forest of Dean, England; Sedim. Geol. 8 177-198.

Klein G De V 1963 Analysis and review of sandstone classifications in the North American Geological Literature, 1940-1960; Geol. Soc. Am. Bull. 77 555-576.

Kreuzer H, Karre W, Kursten M, Schnitzer W A, Murti K S and Srivastava N K 1977 K/Ar dates of two glauconites from the Chandarpur-Series (Chattisgarh/India): on the stratigraphic status of the late precambrian basins in central India; Geol. Jb. B 28 23-36.

Krynine P D 1948 The megascopic study and field classification of sedimentary rocks; J. Geol. 56 130-165.

Krynine P D 1949 The origin of red beds; Trans. New York Acad. Sci. Ser. II 2 60-68.

Kuenen $\mathrm{Ph} \mathrm{H} 1959$ Experimental abrasion 3: Fluviatile action on sand; Am. J. Sci. 257 172-190.

Kuenen Ph H 1960 Experimental abrasion 4: Eolian action; J. Geol. 68 427-449.

McBride E F 1987 Diagenesis of the Maxon sandstone (Early Cretaceous), Marathon region, Texas: a diagenetic quartzarenite; J. Sedim. Petrol. 57 98-107.

Moitra A K 1995 Depositional environmental history of Chattisgarh Basin, M.P., based on stromatolites and microbiota; J. Geol. Soc. India 46(4) 359-368.

Moss A J 1962 The physical nature of common sandy and pebbly deposits, Part I; Am. J. Sci. $260337-373$.

Moss A J 1963 The physical nature of common sandy and pebbly deposits; Part II; Am. J. Sci. 261 297-343.

Murti K S 1987 Stratigraphy and sedimentation in Chattisgarh Basin; In: Purana basins of peninsular India (Mem. Geol. Soc. India, Bangalore) 6 239-260. 
Murti K S 1996 Geology, sedimentation and economic mineral potential of the south-central part of Chattisgarh Basin; Geol. Surv. India Mem. 125139.

Naqvi S M and Rogers J J W 1987 Precambrian Geology of India; (Oxford University Press, New York, U.S.A.) p. 223.

Nemec W and Steel R J 1984 Alluvial and coastal conglomerates: their significant features and some comments on gravelly mass-flow deposits; In: Sedimentology of Gravels and Conglomerates (eds) E H Koster and R J Steel, Canadian Soc. Petrol. Geol. Mem. 10 1-31.

Patranabis Deb S and Chaudhuri A K 2002 Stratigraphic architecture of the Proterozoic succession in the eastern Chattisgarth Basin, India: tectonic implications; Sedimentary Geology 147 105-125.

Pettijohn F J 1984 Sedimentary Rocks; (3rd edn) CBS Publishers, Delhi (1st Indian edn) p. 628.

Pettijohn F J, Potter P E and Siever R 1987 Sand and Sandstone; (2nd edn), (New York: Springer-Verlag) p. 533.

Powers M C 1953 A new roundness scale for sedimentary particles; J. Sedim. Petrol. 23 117-119.

Sanderson I D 1984 Recognition and significance of inherited quartz overgrowths in quartz arenites; J. Sedim. Petrol. 54 473-486.

Shinn E A 1973 Carbonate coastal Accretion in an Area of Longshore Transport, NE Qatar, Persian Gulf; In: The Persian Gulf (ed.) B H Purser (Berlin: Springer-Verlag) Pp. 179-191.

Suttner L J and Basu A 1985 The effect of grain size on detrital modes: a test of the Gazzi-Dickinson point- counting method - Discussion; J. Sedim. Petrol. 55 616-617.

Suttner L J, Basu A and Mack G H 1981 Climate and the origin of quartz arenites; J. Sedim. Petrol. 51 1235-1246.

Suttner L J and Dutta P K 1986 Alluvial sandstone composition and paleoclimate. 1. Framework mineralogy; J. Sedim. Petrol. 56 329-345.

Tortosa A, Palomares M and Arribas J 1991 Quartz grain types in Holocene deposits from the Spanish Central System: some problems in provenance analysis; In: Developments in Sedimentary Provenance Studies (eds) A C Morton, S P Todd and P D W Haughton, Geol. Soc. London, Spec. Publ. 57 47-54.

Turner P 1980 Continental red beds; Developments in Sedimentology (Amsterdam: Elsevier) 29536.

Van Houten F B 1972 Iron and clay in tropical savannah alluvium, Northern Columbia: a contribution to the origin of red beds; Bull. Geol. Soc. America 83 2761-2772.

Van Houten F B 1973 Origin of red beds: a review, 19611972; Ann. Rev. Earth and Planet. Sci. 1 39-61.

Visher G A 1969 Grain size distributions and depositional processes; J. Sedim. Petrol. 39 1074-1106.

Walker R G 1967 Colour of recent sediments in tropical Mexico: a contribution to the origin of red beds; Bull. Geol. Soc. America 78 917-920.

Young S W 1976 Petrographic textures of detrital polycrystalline quartz as an aid to interpreting crystalline source rocks; J. Sedim. Petrol. 46 595-603.

Zuffa G G, Cibin U and Giulio A D 1995 Arenite petrography in sequence stratigraphy; J. Geol. 103 451-459. 